\title{
Industrialisasie van gevorderde tegnologieprodukte met lae volume
}

\author{
René Uys* en Eric Pieters \\ Nagraadse Skool vir Bestuurswese, Potchefstroomse Universiteit vir Christelike Hozr Onderwys, Potchefstroom 2520 \\ Republiek van Suid-Afrika
}

Ontvang 11 April 1990; goedgekeur 5 Julie 1990

\begin{abstract}
Industrialisation of advanced technology products with low volume A noticeable revolution has occured in the manner in which products are produced. Mainly due to an increase in productivity in order to achieve prosperity and progress, a rapid change in technology due to an increase in research and development, and the growing complexity of both the product and the technique to produce it. This requires that more emphasis is placed on the thorough industrialisation of high technology products. Problems are experienced with regard to communication, involvement during the different project life-cycle phases, cultural differences between development and production, documentation management, component manufacturing, instruments, manpower and low volumes during the transfer phase by high-technology companies. In this article the focus is on the project management approach as a possible mechanism to deal with the mentioned problems and to manage the production of high-technology products with a low volume.
\end{abstract}

'n Merkbare revolusie het in die wyse waarop produkte geproduseer word, plaasgevind - hoofsaaklik weens verhoogde produktiwiteit wat nodig is vir groeiende welvaart en vooruitgang, die snelle verandering in tegnologie weens toenemende navorsing en ontwikkeling en die groeiende kompleksiteit van beide die produk en die tegniek om die produk te produseer. Dit bring mee dat meer klem op die deeglike industrialisasie van gevorderde tegnologieprodukte gelê moet word. Probleme word egter tans tydens die oordragfase ten opsigte van kommunikasie, betrokkenheid tydens die verskillende projeklewensiklusfases, kultuurverskille tussen ontwikkeling en produksie, dokumentasiebestuur, komponentvervaandiging, gereodskap, mannekrag en lae volumes deur tegnologie-organisasies ondervind. In dié artikel word op die projekbestuursbenadering gefokus as 'n moontlike meganisme om genoemde probleme aan te spreek in die bestuur van die vervardiging van gevorderde tegnologieprodukte met 'n lae volume.

*Aan wie korrespondensie gerig moet word.

'In today's global economy, it's more critical than ever that research and manufacturing be dancing to a single tune. The tune is the same everywhere. In any language, the lirics translate: whatever the consumer wants, the consumer gets. And what the consumer wants is the highest quality product, with real and perceived value, at the lowest possible costs' (Barrett, 1986: 23).

\section{Probleemstelling}

Die komplekse aard van gevorderde tegnologieprodukte tesame met lae produksievolumes gee aanleiding tot verskeie probleme. Deur slegs na enkele van hierdie probleme te verwys, kan die behoefte aan vaartbelyning van die industrialisasie van sodanige produkte reeds geïdentifiseer word.

Gedurende die oordragproses van gevorderde tegnologieprodukte vanaf ontwikkeling na produksie ontstaan 'n leemte. Wolff beskryf die oordragleemte as

'... the inevitable confrontation of human resistance to change, urgency to meet product schedules, new technology infusion into products, interdiscipline language problems, continuing design alterations and corporate cash commitments, to name but a few'. (1985: 9)

Die grootste enkele probleem volgens Frosch (1984: 11 ) is die feit dat die oordragproses ' $n$ menslike proses is wat deur persone wat met mekaar moet saamwerk, uitgevoer word. In teenstelling hiermee word die oordragleemte dikwels as ' $n$ organisatoriese knelpunt of kommunikasieprobleem beskou en ervaar, wat slegs deur die instel van geskikte verslaggewing en beplanning en beheerstelsels in die organisasie hanteer sal kan word.

Die industrialisasie van gevorderde tegnologieprodukte met lae volume, vereis volgens Clawson (1985: 6) 'n effektiewe projekbestuursbenadering omdat 'it's low-volume, high-tech nature, magnifies and expands the number of natural pitfalls in the production cycle'. Die beplanning en beheer van gevorderde tegnologieprodukte met lae volume is ook 'n kritiese faktor in die industrialisasieproses.

Vanwee die snelle verandering op gevorderde tegnologievlak is dit vir 'n individu of departement onmoontlik om ten volle op die hoogte te bly met die nuutste tegnologiese ontwikkelinge. Tydens die industrialisasieproses van gevorderde tegnologieprodukte word 'n groter verskeidenheid deelnemers dus vereis. Volgens Gray (1985: 7) is die dae van skeiding tussen die ontwikkelingsafdeling en produksieafdeling getel.

Probleme ontstaan omdat die industrialisasiespan cers betrokke rak nadat die ontwikkeling van 'n gevorderde tegnologieproduk in essensie voltooi is. Dit beteken dat daar min of geen koördinering ten opsigte van belangrike produksie-georiènteerde aktiwiteite soos byvoorbeeld bouprosesse, personeelvereistes, toerusting en gereedskap, materiaaltegnologie en fasiliteite bestaan nie.

In die lig van die bogenoemde probleme word in hierdie artikel gepoog om 'n nuwe benadering ten opsigte van die industrialisasieproses van gevorderde tegnologieprodukte met lae volume aan te moedig. 


\section{Doel van die artikel}

Die doel van dié artikel is om 'n model voor te stel vir die industrialisasieproses van gevorderde tegnologieprodukte met lae volume, vanaf ontwikkeling na produksie.

Aandag sal ook gegee word aan die rol en betrokkenheid van die industrialisasiespan by die industrialisasieproses vanaf ontwikkeling tot by produksie. Klem sal gelê word op die belangrikheid van 'n prosesbenadering en die noodsaaklikheid van 'n effektiewe projekbestuursbenadering vir die industrialisasie van hierdie produkte.

\section{Navorsingsmetodlek}

'n Literatuurstudie is onderneem om te bepaal of die probleem nie reeds voorheen aangespreek is en die oplossing reeds tot voordeel van ander gepubliseer is nie. Aanvullend hiertoe is ander beskikbare bronne bestudeer en waar van toepassing in die studie aangewend.

Onderhoude is met twintig vakkundiges (program-, projek-, produksie-, ontwikkelings-, aanskaffings- en kwaliteitsbestuurders) betrokke by die industrialisasie van gevorderde tegnologie gevoer. Al die respondente is verbonde aan gevorderde tegnologie-organisasies gemoeid met die ontwikkeling en produksie van nuwe produkte. Vanwex die feit dat die meeste van die organisasies by die verdediging van die Republiek van SuidAfrika betrokke is, is die bepalings van artikel 118 van die Verdedigingswet, Wet no. 44 van 1957 sowel as die bepalings van die Wet op Amptelike Geheimhouding, Wet no. 16 van 1956 op die organisasies en hulle bedrywighede van toepassing. Daar word egter gepoog om die sensitiewe inligting wat bekom is, so getrou moontlik weer te gee.

\section{Huidige problematlek}

Die onderstaande inligting is gebaseer op die terugvoer wat tydens die onderhoude deur respondente verskaf is.

\section{Kultuurverskille tussen die ontwikkelingsfunksie en die produksiefunksie}

'... research and the dividing of innovative ideas are highly untidy processes ... At the other end of the process, if one is going to manufacture ... there must be an extraordinary degree of tidiness of system, of detail recordkeeping and of great planning' (Frosch, 1984: 11).

Ontwikkeling is 'n eenmalige, toekomsgerigte aktiwiteit wat die vooruitskatting van koste sowel as die deurlopende monitor van prestasie bemoeilik. Daarteenoor behels produksie die maak van produkte op 'n geordende wyse volgens spesifikasie tcen die hoogste kwaliteit en die laagste moontlike prys.

Ontwikkeling en produksie kan dus met reg as twee verskillende kulture met uiteenlopende waardestelsels en belange beskou word. Die ontwikkelingsafdeling glo dat slegs hulle innoverend en kreatief kan wees, terwyl hulle produksie beskou as eenvoudige prosesse wat min interpretasie verg. Die produksie-afdeling aan die ander kant sien die ontwikkelingsafdeling as werkers wat nie konkrete of meetbare doelwitte het nie, en sodoende hulle doelwitte kan aanpas sodat dit binne maklike bereik is. Produksie daarteenoor moet meetbare doelwitte bereik. Produksie-ingenieurs word moeilik deur ontwikkelingsdepartemente aanvaar, alhoewel hulle dieselfde kwalifikasie mag hê as hul kollegas in ontwikkeling.

\section{Kommunikasie}

Kommunikasie is oor die algemeen 'n probleem wat deur organisasies ondervind word. Die volgende probleme is tiperend:

- besitlikheid, sowel as die bevrediging van die ego en strewe na voortdurende erkenning by ingenieurs;

- inligting word weerhou ten einde magsbasisse te versterk; eenrigtingkommunikasie, hoofsaaklik vanaf ontwikkeling en produksie;

- weerstand van die ontwikkelingsafdeling om produksie te aanvaar veroorsaak 'n gebrek aan kontinuiteit tydens die lewensiklus van die projek; en

- organisasiepolitiek afkomstig van bo ('top-down').

\section{Betrokkenheid tydens die verskillende projekle-} wensiklusfases

Betrokkenheid en kommunikasie loop meestal hand aan hand. Ontwikkeling kan vroeæ produksiebetrokkenheid as inmenging in hulle domein sien, produksic moet eers opdragte gegee word voordat hulle betrokke sal raak (reaktiewe betrokkenheid), aanvaardingsprobleme tussen ontwikkeling en produksie en organisasiepolitiek ten opsigte van die beskerming van eie koninkryke ('empires') is tipiese probleme wat in hierdie verband voorkom.

\section{Dokumentasiebestuur}

Dokumentasie is 'n algemene probleem by die oordrag van gevorderde tegnologieprodukte omdat dokumentasie nie altyd versoenbaar is met die hardeware nie. Daarbenewens word onrealistiese spesifikasies toegeken en veranderingsbeheer word nie altyd na betrokke dokumente deurgevoer nie.

Dokumentasie word ook selde ten opsigte van produseerbaarheid (vervaardigbaarheid), proseslimiete, dimensionele analises, standaardisasie, kwaliteit van ontwerp en toereikendheid van gereedskap, spesifieke prosesse, aanvaardingsvereistes en of dit in lyn is met inspeksieprosedures, gemonitor.

\section{Komponentvervaardiging}

Komponentvervaardiging is een van die slaggate waarin byna elke nuwe gevorderde tegnologieproduk tydens die oordrag vanaf ontwikkeling na produksie vasval. Die redes hiervoor is die volgende:

- Geen studie omtrent die vervaardigbaarheid van die komponente word gedoen nie.

- Geen langtermynverbintenis ten opsigte van die komponente word aangegaan nie.

- Aankopers en kwaliteitsversekering help nie die verskaffers of leweransiers met die industrialisasie van hulle prosesse nie. As gevolg daarvan word baie de- 
fektiewe komponente aanvanklik vervaardig.

- Aankopers vervul dikwels net 'n soort poskantoorfunksie wat tot vertragings aanleiding gee, aangesien hulle nie cor die agtergrondinligting ten opsigte van die ontwerpproses beskik nie.

- Die nuutste komponentvervaardigingsdokumente word nie altyd aan verskaffers of leweransiers verskaf nie.

- As gevolg van die steekproefaanvaardingstegniek ('sampling') wat inkomende inspeksies gebruik vir die aanvaarding van komponente, word 'n groot aantal komponente wat ecrder afgekeur moes word, aanvaar.

- Probleme word dikwels met tydskale en koste ondervind wanneer daar slegs een verskaffer of leweransier is.

\section{Gereedskap}

Gereedskap word as een van die mees dinamiese aspekte van die oordrag van gevorderde tegnologieprodukte beskou. Weens 'n gebrek aan kennis ten opsigte van die produksieprosesse van die nuwe produk, word gereedskapsprobleme selfs in die produksiefase ondervind. Probleme soos byvoorbeeld:

- Gereedskap is ontoereikend en onakkuraat.

- Ontwikkeling voel dat slegs hulle bevoeg is om gereedskap (veral gietstukgereedskap) te ontwerp en dat produksie nie oor die nodige ontwerpkundigheid beskik nie.

- Gereedskap word dikwels hör of laer as die werklike werkverrigtingvereistes gespesifiseer.

- Onnodige ontwerpveranderinge gee aanleiding tot die modifisering van gereedskap en 'n gevolglike verlaging in die leeftyd van die gereedskap.

- Onrealistiese standaarde lei tot die misbruik ('abuse') van gereedskap.

\section{Mannekragtekorte}

Volgens die Raad vir Geesteswetenskaplike Navorsing se verslag na Onderwysvoorsiening in die RSA (1981:

24) bestaan daar ' $n$ tekort aan en 'n toename in die vraag na veral tegnies- en tegnologies-opgeleide mannekrag in die RSA. Die tekort noop gevorderde tegnologie-organisasies om tegnies- en tegnologies-opgeleide mannekrag, wat pas hul naskoolse opleiding voltooi het, in diens te neem. Die mannekrag beskik dus nie altyd oor die nodige praktiese ervaring ten opsigte van aspekte soos produseerbaarheid, onderhoubaarheid, betroubaarheid en gebruikersvriendelikheid van produkte nie. 'n Organisasie verloor ook kontinuiteit van kennis as mannekrag verplaas word, of die organisasie verlaat.

\section{Lae volumes}

Al die gevorderde tegnologie-organisasies wat aan die navorsing deelgeneem het, het gemeld dat hul ten minste een klant met beperkte behoeftes het. 'n Verskeidenheid gevorderde tegnologieprodukte word dus benodig om die klant tevrede te stel. As gevolg hiervan word gevorderde tegnologieprodukte in lae volumes gepro- duseer wat daartoe lei dat selde voldoen kan word aan die beginsel van ' $n$ gesonde leerkurwe.

\section{Internasionale boikotte}

Menige Suid-Afrikaanse tegnologie-nywerhede gaan gebuk onder intemasionale boikotte. Gevolglik is die organisasies in 'n groot mate geïsoleerd van die gevorderde tegnologieprodukte of stelsels van die buiteland. Die organisasies kan nie hulle stelsels geredelik of vrylik aan die buitelandse evaluasiemarkte bekendstel nie en kan ook nie evaluasie-inligting ten opsigte van corsese produkte of stelsels vrylik bekom nie. Dit gee aanleiding tot verhoogde koste en onverfynde produkte.

\section{Ontwikkelingsmodelle}

Tydens die ontwikkelingsfase ontwerp die ontwikkelingsingenieur die produk of stelsel en ken dan toleransies toe aan elke afmeting. Die ontwerp word aan protowerkwinkels oorhandig wat die komponente vervaardig. Vyf tot tien stelle komponente word dan deur spesialiste van die bedryf vervaardig en noukeurige aandag word aan die opstel van die masjinerie en toerusting gegee. Al die komponente word dus so na as moontlik aan die presiese afmetings vervaardig. Passingsprobleme word selde ondervind as die ontwikkelingsmodelle saamgestel word, en so word swak of gebrekkige dimensionele analise dikwels nie tydens die ontwikkelingsfase bemerk nie.

Tydens die industrialisasiefase word produkte of stelsels uit die produksiekomponente opgebou. Produksiekomponente word in verskeie lotte deur leweransiers in die industrie vervaardig. Alhoewel masjinerie volgens die toleransiegrense opgestel en komponente daarbinne vervaardig word, gebeur dit wel soms dat daar tussen die boonste en onderste limiet verskille is en word daar dikwels passingsprobleme, wanneer verskillende komponente saamgestel word, ondervind. Dit kan meebring dat komponente soms oorgemaak of selfs geskroot moet word.

\section{Standaardisasie}

Frosch (1984: 11) beskryf die ontwerp- en die ontwikkelingsmannekrag as kreatiewe en innoverende mense. Vir hierdie mense impliseer standaardisasie die ontneming van kreatiwiteit en innovasie, en daarom word standaardisasie vermy.

Standaardisasie kan egter 'n uitdaging aan die ontwerp- en ontwikkelingsmannekrag stel, soos die opneem van bestaande subontwerpe in hulle ontwerp en die gebruik van standaardmateriaalvorme en -items.

Gebrek aan standaardisasie lei tot verhoogde vervaardigingskoste, die aanhou van 'n groter verskeidenheid voorraad asook 'n verhoging in administrasie. Verskillende spesifikasies word ook dikwels aan soortgelyke produkte of stelsels gegee wat bottelneksituasies by die aanvaardingsfasiliteite soos onder andere omgewingstoetse en kwaliteitsversekering laat ontstaan. Die produksieprosesse word dikwels bemoeilik of raak te kompleks weens 'n gebrek aan standaardisasie tydens die ontwikkelingsfase. 
Teen die agtergrond van genoemde probleme en in die soeke na ' $n$ oplossing vir die probleme, is veral op projekbestuursbenaderingsteoriex gelet. Die projekbestuursbenadering word deur Archibald (1976: III) as 'one of the most significant contributions to management theory and practice' beskryf, omdat 'not only has innovative organizational approaches been developed to facilitate the effective integration of people, resources, and tasks, but equally important, powerful management systems to monitor and control projects have been devised'.

Voorgestelde model vir die Industrialisasieproses van gevorderde tegnologieprodukte

Tot dusver is die probleme wat by die industrialisasieproses van gevorderde tegnologieprodukte met lae volume ondervind word, geskets. Vervolgens word 'n model vir die industrialisasieproses van gevorderde tegnologieprodukte met lae volume, wat hierdie probleme grootliks aanspreek, voorgestel. Die model bestaan uit drie fases wat elk weer 'n subproses van die totale industrialisasieproses uitmaak, naamlik: die ondersoekfase, die ontwikkelingsfase en die industrialisasiefase. In Figuur 1 word 'n uiteensetting van die industrialisasieproses gegee.

\section{Die ondersoekfase}

Die industrialisasieproses begin reeds tydens die ondersoekfase wat die konsep- en definisiefase insluit, waartydens die ontwerpingenieur, wat die sleutelfiguur is, verantwoordelik is vir die daarstelling van die konsepontwerp. Die lewensvatbaarheid van die konsep word deur middel van die toepassing van normale ingenieursbeginsels bewys.

Die industrialisasiespan lewer insette tot alle moontlike produksiegeoriënteerde aktiwiteite wat tydens die ontwikkeling van die produk oorweging moet geniet. In Figuur 2 word 'n uiteensetting van die industrialisasieproses tydens die ondersoekfase gegee.

\section{Insette}

Die primêre inset wat tot die inisiěring van die proses aanleiding gee, is die gebruikerbehoeftestelling (GBS), met ander woorde die behoefte wat die gevorderde tegnologieproduk moet bevredig.

\section{Prosesaktiwiteite}

Die cerste aktiwiteit wat plaasvind, behels die onuleding

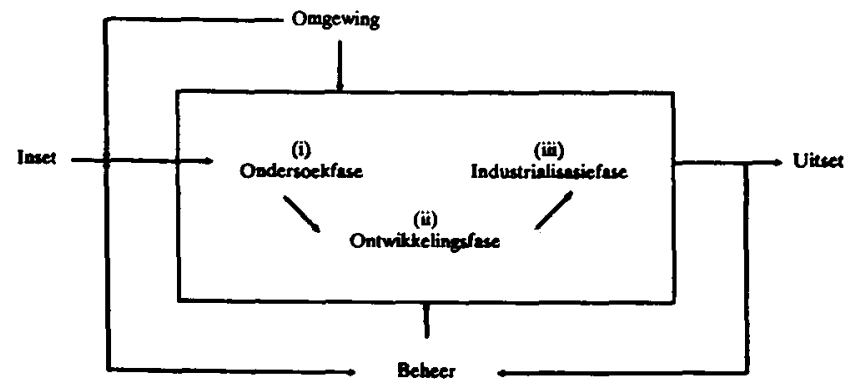

Figuur 1 Die industrialisasieproses

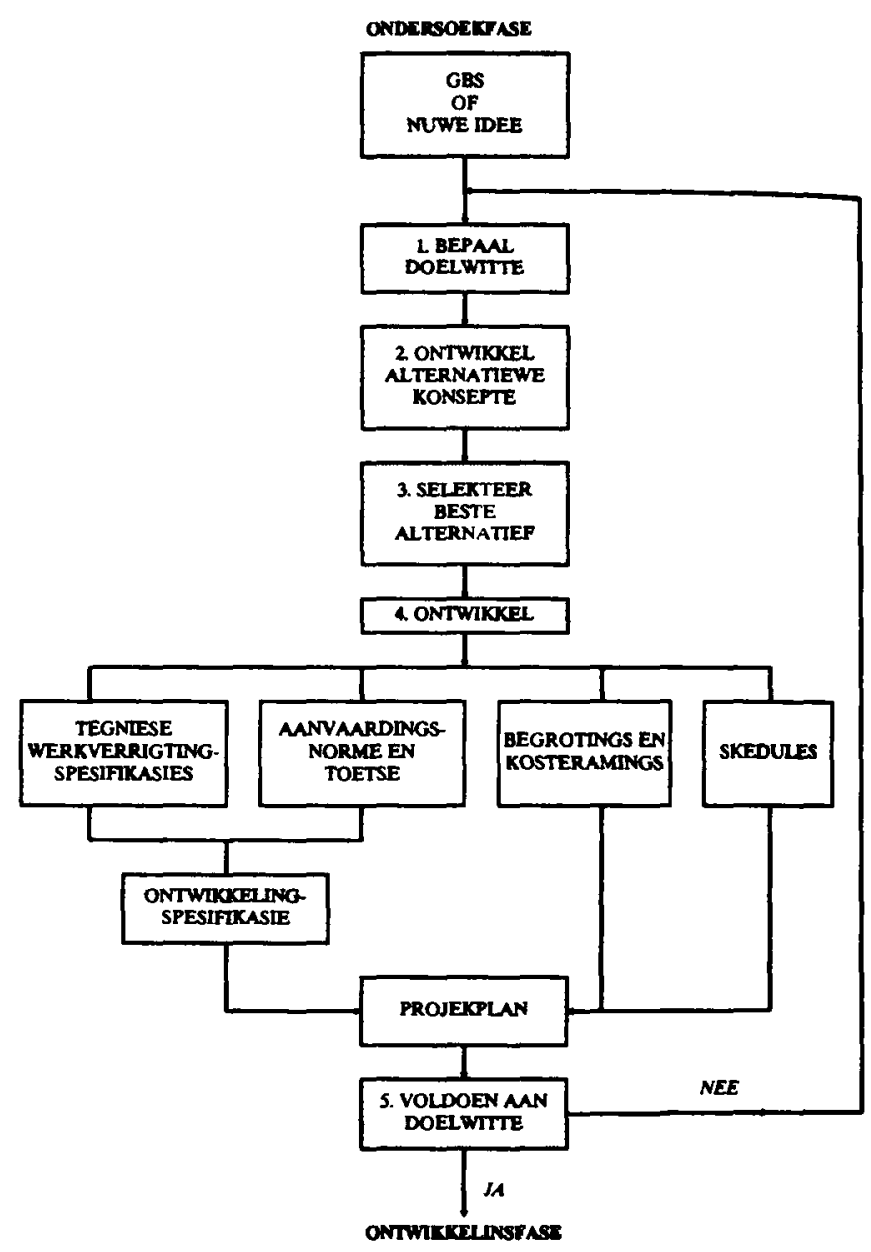

Figuur 2 Industrialisasie tydens die ondersoekfase

van die behoeftes, die bepaling van voorkeure en die daarstelling van doelwitte ten opsigte van die verwagte uitset. Elemente van die groter omgewing, asook die makrovlak van die omgewing, word in ag geneem.

Die tweede aktiwiteit behels die ondersoek en daarstelling van al die moontlike alternatiewe konsepte ten einde te voldoen aan die gestelde doelwitte. Tydens dié aktiwiteite word veral gelet op die taakomgewing asook op die intermediêre vlak van die omgewing. Insette soos mannekrag, kapitaal, materiaal, tegnologie en alle ander inligting beskikbaar, word oorweeg.

Die derde aktiwiteit behels die selektering van die mees geskikte en lewensvatbare alternatief. Tydens dié aktiwiteit word veral gelet op die mikrovlak van die omgewing.

Die vierde aktiwiteit behels die ontwikkeling van die ontwerpspesifikasies vir die nuwe gevorderde tegnologieproduk. Dié aktiwiteit sluit vier aksies in naamlik tegniese werkverrigtingspesifikasies, aanvaardingspesifikasies, begroting en kosteberaming en tydskale en skedules.

Die uitvloeisel van die tegniese werkverrigtingspesifikasies en aanvaardingspesifikasies is ' $n$ ontwikkelingspesifikasie. Al vier aksies word in 'n projekplandokument saamgevat. Tydens dié aktiwiteite word veral gelet op die karakteristieke wat die proses kenmerk, soos effektiwiteit en doeltreffendheid van die ontwikkeling spesifikasies, die kapasiteit van die organisasie se 
fasiliteite asook die mate van buigsaamheid teenwoordig in die ontwerp.

Die vyfde aktiwiteit behels die voldoening aan die gebruikersbehoeftestelling (GBS). Dié aktiwiteit word tydens ' $n$ hersiening van die ontwerp deur die klient of gebruiker aanvaar of afgekeur. Indien die aktiwiteit aanvaar word, dien die projekplan as basislyn vir die volskaalse ontwikkelingsfase. Indien die aktiwiteit afgekeur word, word die proses herhaal totdat 'n aanvaarbare of lewensvatbare ontwerp gekry word.

\section{Uitsette}

Die uitset van hierdie fase, is 'n goedgekeurde ontwikkelingspesifikasie vervat in die projekplan wat as basislyn vir die volskaalse ontwikkelingsfase dien. In Tabel 1 word 'n voorbeeld van 'n tipiese verantwoordelikheidsmatriks ten opsigte van die betrokkenheid van die groter organisasie gegee.

\section{Die ontwikkelingsfase}

Tydens die ontwikkelingsfase is die ontwikkelingsprojekbestuurder, die sleutelfiguur, verantwoordelik vir die gedetailleerde ontwerp en ontwikkeling van die gevorderde tegnologieproduk deur gebruik te maak van die normale ingenieursbeginsels.

Die industrialisasiespan lewer insette ten opsigte van alle moontlike produksiegeoriënteerde aktiwiteite wat tydens die ontwikkeling van die produk oorweging moet geniet. In Figuur 3 word 'n uiteensetting gegee van die industrialisasieproses tydens die ontwikkelingsfase.

Insette

Die inset wat die industrialisasieproses tydens die ontwikkelingsfase inisieer, is 'n goedgekeurde ontwikkelingspesifikasie vervat in die projekplan was as basislyn vir die volskaalse ontwikkeling dien.

\section{Prosesaktiwiteite}

Die eerste aktiwiteit behels die bepaling en definiěring van die doelwitte benodig vir die ontwikkeling van die gevorderde tegnologieproduk.

Die tweede aktiwiteit behels die gedetailleerde ontwerp vir elke konfigurasie-item gevorderde tegnologieproduk. Tydens die aktiwiteit word die ontwerp volledig gedokumenteer en volgens 'n meesterrekordindeks (MRI) beheer. Verder behels dit die bou van die ontwikkelingsmodelle volgens die gedetailleerde ontwerp.

Die komponente benodig vir die samestelling van die konfigurasie-items word volgens die MRI-tekeninge gemaak. Die makk van die komponente word deeglik gemonitor. Daarna word die konfigurasie-items saamgestel en geèvalueer vir die mate waartoe hulle aan fisiese en funksionele karakteristieke voldoen. Alle afwykings word aangeteken terwyl die MRI-dokumente dienooreenkomstig opgedateer word.

As uitvloeisel van dié aktiwiteit word die ontwerp her-

Tabel 1 Tipiese verantwoordelikheidsmatriks vir die ondersoekfase

Legende

V: Verantwoordelikheid

T: Taak

I: Insette

\section{NDUSTRIALISASIEPROSES TYDENS DIE ONDERSOTKFASE}

\section{A. INSETTE}

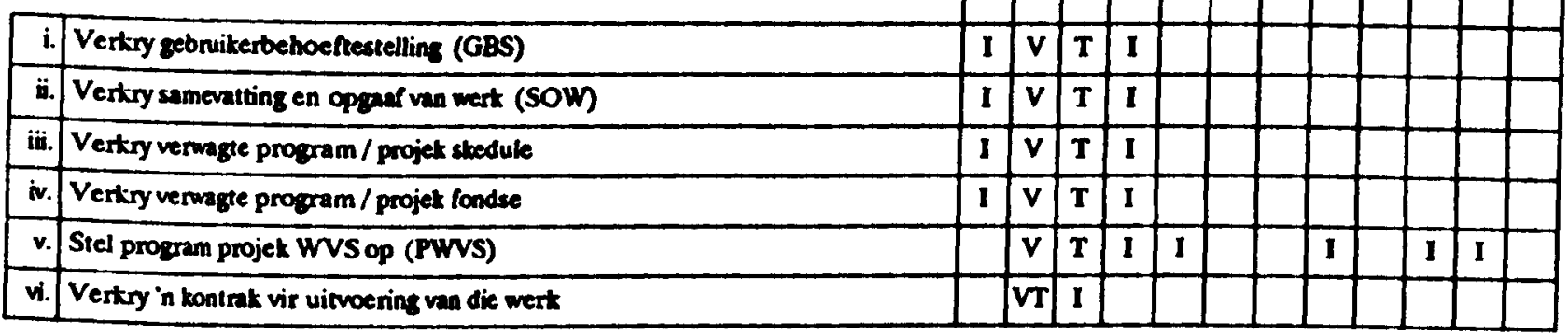

\section{PROSESAKTIWTITITE}

Berste Altwiklt : Bepal doelwite

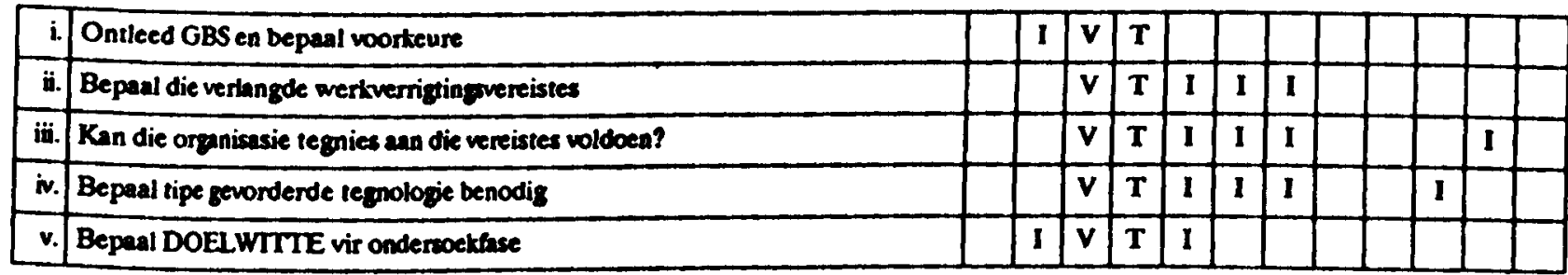


Tabel 1 (vervolg)

Legende

V: Verantwoordelikheid

T: Taak

I: Insette

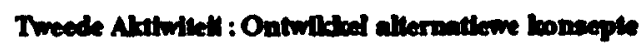

\begin{tabular}{|c|c|c|c|c|c|c|c|c|c|c|c|c|}
\hline i. & Ontwilitel alle moontlike konsepte & I & $\mathbf{V}$ & $\mathbf{T}$ & I & $\mathbf{I}$ & & & & & & \\
\hline \multirow[t]{5}{*}{ ii. } & Bepal tegnologie vereintes van elle konsep & & $\mathbf{V}$ & $\mathbf{T}$ & I & I & I & & & & & \\
\hline & - Bestana die tegnologie? & I & $\mathbf{V}$ & $\mathbf{T}$ & $\mathbf{I}$ & $\mathbf{I}$ & I & & & & & \\
\hline & - Moet dit ontwilkkel wond? & $\mathbf{I}$ & $\mathbf{V}$ & $\mathbf{T}$ & $\mathbf{I}$ & I & I & & & $\mathbf{I}$ & & \\
\hline & - Wat is die koste verbonde ane die tegnologie? & I & $\mathbf{V}$ & $\mathbf{T}$ & $\mathbf{I}$ & 1 & 】 & & & I & & \\
\hline & - Wat is die tydskale benodig vir die vestiging van die tegnologje? & I & $\mathbf{V}$ & $\mathbf{T}$ & 1 & I & I & & & $\mathbf{I}$ & & \\
\hline iii. & Evalucer die tegnolopie beskikbuar in organisesie in terme van ellise koneep & & $\mathbf{V}$ & $\mathbf{T}$ & 1 & $\mathbf{I}$ & I & & & & & \\
\hline \multirow[t]{7}{*}{ iv. } & Bepaal die material vereistes van elke konsep & & $\mathbf{V}$ & $\mathbf{T}$ & $\mathbf{I}$ & $\mathbf{T}$ & I & & & & & \\
\hline & - Wat is die strategiese waarde van materiaal vereistes? & & $\mathbf{V}$ & I & & $\mathbf{T}$ & & & & I & & \\
\hline & - Is die material beskikbaar in mart? & & $\mathbf{V}$ & I & $\mathbf{I}$ & $\mathbf{T}$ & I & & & & & \\
\hline & - Wie is die moontlike versliaffers? & & $\mathbf{V}$ & I & $\mathbf{I}$ & $\mathbf{T}$ & I & & & $\mathbf{I}$ & & \\
\hline & - Moet die materiaalvervaandigingovermot gevestig word? & & $\mathbf{V}$ & $\mathbf{I}$ & & $\mathbf{T}$ & & & & I & & \\
\hline & - Wat is die koste verbonde aan dic materiaal? & I & $\mathbf{V}$ & $\mathbf{r}$ & & $\mathbf{T}$ & & & & & & \\
\hline & - Wat is die tydstiale benodig vir die vestiging van die vervaardigingavermot? & $\mathbf{I}$ & $\mathbf{v}$ & $\mathbf{I}$ & & $\mathbf{T}$ & & & & & & \\
\hline \multirow[t]{2}{*}{$\mathbf{v}$} & Bepaal die fasiliteitsvereistes van ellbe konsep & & $\mathbf{V}$ & $\mathbf{T}$ & $\mathbf{T}$ & $\mathbf{I}$ & I & & & & & \\
\hline & - Evalueer die huidige fasiliteitovermot in terme van elke konsep & & $\mathbf{v}$ & $\mathbf{T}$ & $\mathbf{T}$ & I & 1 & & & & & \\
\hline \multirow[t]{6}{*}{ vi. } & Bepaal die kapitale toerustingvereistes van ellse kosep & $\mathbf{I}$ & $\mathbf{v}$ & $\mathbf{T}$ & $\mathbf{T}$ & $\mathbf{I}$ & I & & & & & I \\
\hline & - Watter vervaardiging / produlsic toerusting word benodig? & & $\mathbf{V}$ & & $\mathbf{T}$ & 1 & I & & & & & \\
\hline & - Watter toetstoenusting word benodig? & & $\mathbf{v}$ & $\mathbf{T}$ & $\mathbf{I}$ & $\mathbf{I}$ & $\mathbf{I}$ & & & & & \\
\hline & - Wat is reeds beslikbanr in dic orranisasie? & & $\mathbf{v}$ & $\mathbf{T}$ & $\mathbf{T}$ & $\mathbf{I}$ & I & & & & & \\
\hline & - Wie is die moontlike versliafters? & & $\mathbf{v}$ & $\mathbf{I}$ & I & $\mathbf{T}$ & I & & & 】 & & \\
\hline & - Wat is die kosre verbonde an die kapitale toerusting? & I & $\mathbf{V}$ & I & I & $\mathbf{T}$ & $\mathbf{I}$ & & & & & \\
\hline \multirow[t]{5}{*}{ vii. } & Bepeal die vervaardiginga- en produlsievermot benodig deur elke konsep & & $\mathbf{V}$ & $\mathbf{I}$ & $\mathbf{T}$ & & I & & & & & \\
\hline & - Watter spesidie prosesse word voorsien en benodic? & & $\mathbf{V}$ & I & $\mathbf{T}$ & & I & & & & & \\
\hline & - Wat is reeds beslikbana in die orranisasie? & & $\mathbf{v}$ & I & $\overline{\mathbf{T}}$ & & I & & & & & \\
\hline & - Wat is die koste vertonde ann die vestiging van spesinle procedure? & I & $\mathbf{V}$ & $\mathbf{I}$ & $\mathbf{T}$ & & 1 & & & & & \\
\hline & - Wat is die tydskale benodig vir die vestiging van die vermoz? & I & $\mathbf{V}$ & I & $\mathbf{T}$ & & & & & & & \\
\hline \multirow[t]{5}{*}{ viii. } & Bepaal die mannelirag vereistes van elke konsep & & $\overline{\mathbf{V}}$ & $\mathbf{I}$ & 1 & 1 & I & 1 & I & I & $\mathbf{T}$ & \\
\hline & - Wat is die verlande kundigheid? & & $\mathbf{V}$ & $\mathbf{I}$ & 1 & & & & & & $\mathbf{T}$ & \\
\hline & - Wat is die manneluag behoefte? & & $\mathbf{v}$ & I & I & & & & & & $\mathbf{T}$ & \\
\hline & - Wat is die selerheidsklaring benodig? & & $\mathbf{V}$ & I & 1 & & & & & I & $\mathbf{T}$ & \\
\hline & - Wat is bestrilbaar in die orranisasie? & & $\bar{v}$ & I & 1 & & & & & & $\mathbf{T}$ & \\
\hline ix. & Bepaal die tydskale benodig deur elke konsep & $\mathbf{I}$ & $\mathbf{v}$ & $\mathbf{T}$ & I & $\mathbf{I}$ & I & & & I & $\mathbf{I}$ & \\
\hline $\boldsymbol{x}$. & Vergeht die tydstiale verksy van die geobruiker (inseet) & $\mathbf{I}$ & $\mathbf{v}$ & $\mathbf{T}$ & & & & & & & & \\
\hline $\mathbf{x i}$ & Beptal die verwagte fondse benodig deur elle konsep & I & $\mathbf{v}$ & $\overline{\mathbf{T}}$ & 1 & & & & & & & \\
\hline xii. & Vergebt met fondse inligring vertsy vanaf gebruiker (inset) & $\mathbf{I}$ & $\mathbf{V}$ & $\mathbf{T}$ & & & & & & & & \\
\hline
\end{tabular}


Tabel 1 (vervolg)

Legende

V: Verantwoordelikheid

T: Taak

I: Insette

Dende Altwhelt : Solekteer beake shernathet

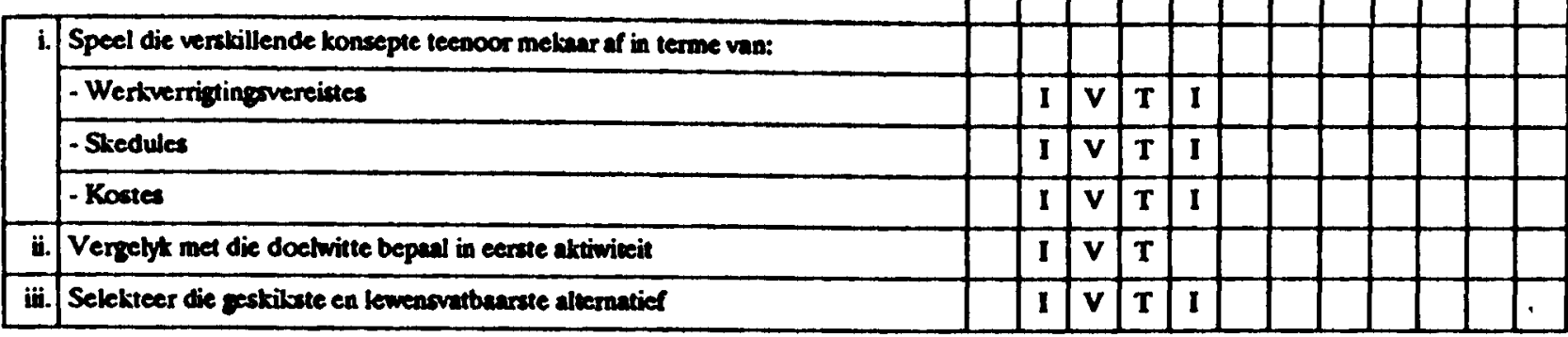

Viende Altwtiell : Ontwiklel ontwerpopesilnesses

\begin{tabular}{|c|c|c|c|c|c|c|c|c|c|c|}
\hline i. & Ontwikkel tegniese wertwerrigtingspesifiliasies & $\mathbf{I}$ & $\mathbf{V}$ & $\mathbf{T}$ & $\mathbf{I}$ & $\mathbf{I}$ & & & & \\
\hline ii. & Ontwiblef anuvandinganorme en loetsprosedures & $\mathbf{I}$ & $\mathbf{v}$ & $\mathbf{T}$ & I & I & I & & & \\
\hline iii. & Let op vir standeand isesie van spestifitasties & $\mathbf{I}$ & $\mathbf{V}$ & $\mathbf{T}$ & $\mathbf{T}$ & $\mathbf{T}$ & I & & & \\
\hline iv. & Bepanl die beraamde lewe nsiklustioste vir die projek & $\mathbf{I}$ & $\mathbf{v}$ & $\mathbf{T}$ & $\mathbf{I}$ & $\mathbf{I}$ & $\mathbf{I}$ & & & $\mathbf{I}$ \\
\hline v. & Beplan die tydsduur van die ontwitkeliness-, industrialisesie- en produbsiefases & 1 & $\mathbf{V}$ & $\mathbf{T}$ & $\mathbf{T}$ & $\mathbf{I}$ & I & & & $\mathbf{I}$ \\
\hline vi. & Stel die projekplan dokument saam & $\mathbf{I}$ & $\mathbf{V}$ & $\mathbf{T}$ & I & & & & I & \\
\hline vii. & Plaas projelplan dokument onder konfigurasiebeatusur & 1 & $\mathbf{v}$ & I & & & & $\mathbf{T}$ & I & \\
\hline
\end{tabular}

Vylde Altwtell : Voldoen man doebulthe

\begin{tabular}{|c|c|c|c|c|c|c|c|c|c|c|c|}
\hline i. & Reel in hersiening van die ontwerp vergadering & I & 1 & $\mathbf{v T}$ & $\mathbf{I}$ & I & 1 & 1 & $\mathbf{I}$ & I & I \\
\hline \multirow[t]{4}{*}{ ii. } & Vergelyte en evalueer die prestasie ven die ontwerp teerwar die doelwilte in teme van: & & & & & & & & & & \\
\hline & - Werkverrigting & I & 1 & $\mathbf{v T}$ & I & 1 & 1 & $\mathbf{I}$ & & & \\
\hline & - Skedules & I & 1 & VT & I & I & & & & & \\
\hline & - Kostes & I & 1 & $\mathbf{V T}$ & I & 1 & & & & & \\
\hline iii. & Bepaal die mate waartoe ontwerp an GBS voldoen & $\mathbf{I}$ & 1 & VT & I & $\mathbf{I}$ & & & & & \\
\hline iv. & Ontwerp nic annvaasanr, begin weer by cerste aktiviteit & 1 & $\mathbf{I}$ & VT & I & & & & & & \\
\hline v. & Ontwerp annvarbaar, projekplan dien as basialyn vir ontwilktelingatase & $\mathbf{I}$ & I & $\mathbf{v T}$ & $\mathbf{I}$ & & & & & & \\
\hline
\end{tabular}

\section{IITSETTE}

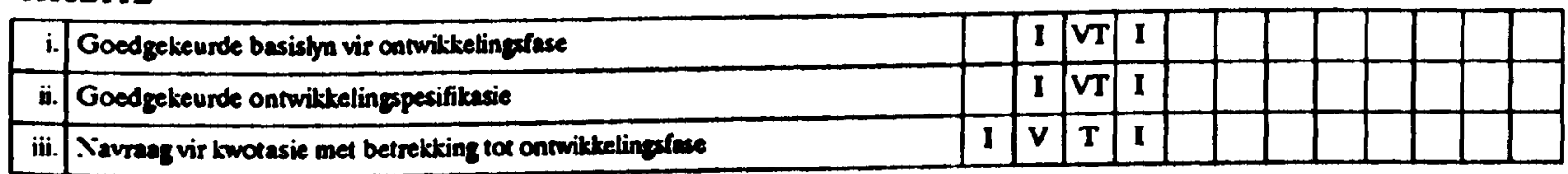

sien. Tydens 'n vergadering tussen die gebruiker en die industrialisasiespan word alle konfigurasie-items hersien vir aspekte soos die volgende:

- die evaluering van die vordering, die tegniese werkverrigting (effektiwiteit en doeltreffendheid) asook die eliminering van risiko-areas;

- die haalbaarheid en verenigbaarheid met betrekking tot vereistes soos betroubaarheid, onderhoubaarheid en produseerbaarheid; en

- die bepaling van en verenigbaarheid met betrekking tot die fisiese en funksionele intervlakke tussen die konfigurasie-items en ander items, toerusting, fasiliteite en personeel (Armscor, 1984: 21).

Die derde aktiwiteit behels dat die doelwitte bereik 


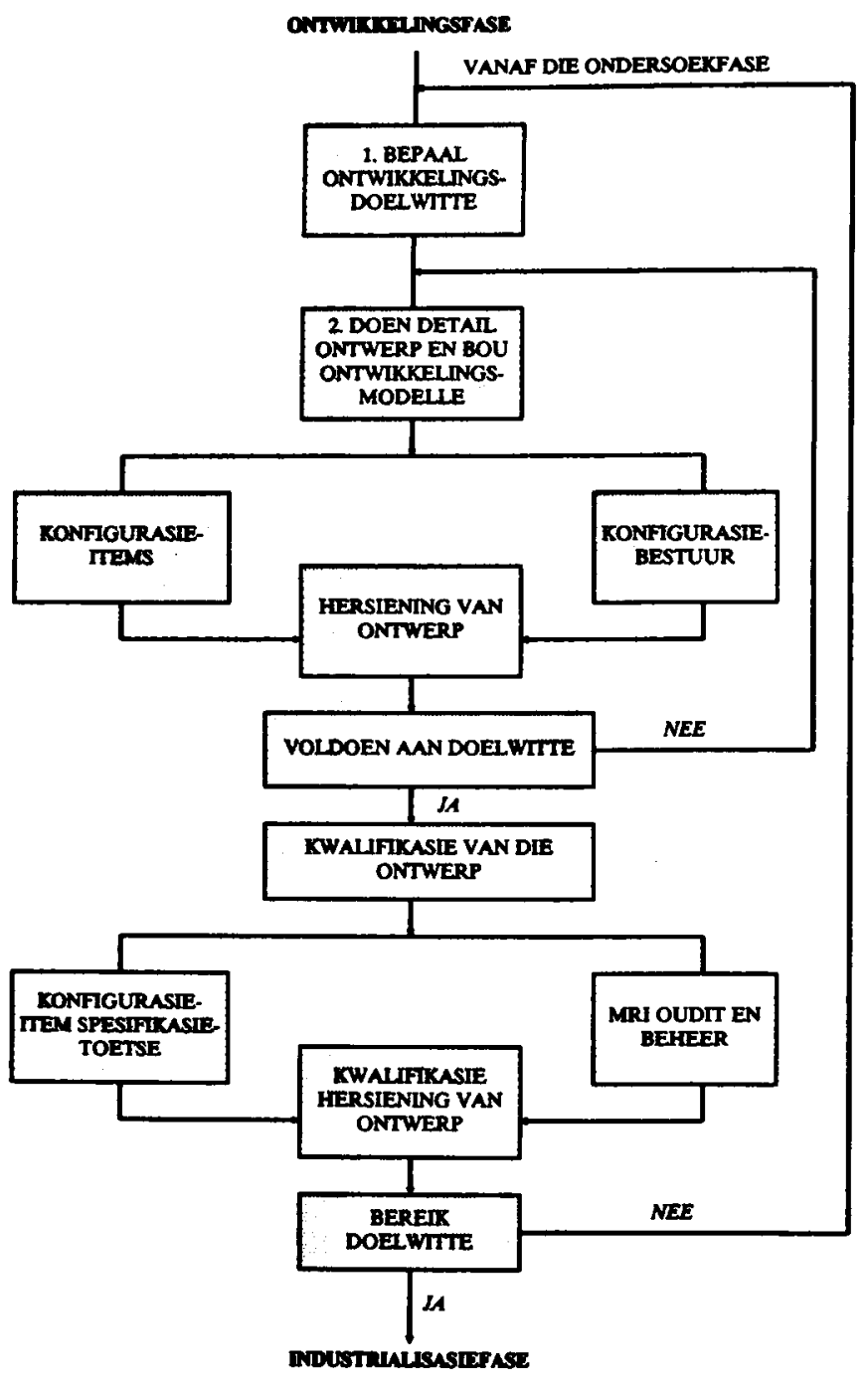

Figuur 3 Industrialisasie tydens die ontwikkelingsfase

moet word soos bepaal in die eerste aktiwiteit. Indien nie aan die doelwitte voldoen word nie, word verdere ontwikkelingsmodelle gebou. Indien aan die doelwitte voldoen word, word voortgegaan met die kwalifikasie van die ontwerp.

Die vierde aktiwiteit behels die kwalifikasie van die ontwerp. Dit is die proses waartydens die ontwerp volgens die spesifikasies van elke konfigurasie-item, onder gekontroleerde omstandighede, ten opsigte van passing, funksie en vorm geverificer word. Die aktiwiteit sluit twee aksies in naamlik: konfigurasie-itemspesifikasietoetse en MRI-oudit en beheer.

Die uitvloeisel van dié aktiwiteit is 'n kwalifikasiehersiening van die ontwerp, en tydens 'n vergadering word die resultate, leemtes en voorgestelde korrektiewe aksies, waar nodig, ten opsigte van die volgende aspekte weer bespreek:

- Stel vas of die konfigurasie-items, wat onderworpe was aan die kwalifikasie van die ontwerp, die spesifikasies, betroubaarheid en onderhoubaarheidsvereistes bevredig het.

- Die bepaling van stelselverenigbaarheid tussen die konfigurasie-items en ander items, toerusting, fasili- teite en personeel.

- Voorsiening van produksierisiko-areas.

- Produk- of stelselspesifikasies.

Die vyfde aktiwiteit behels die bereiking van die doelwitte soos bepaal in die eerste aktiwiteit. Indien die doelwitte nie bereik word nie, word teruggekeer na die eerste aktiwiteit. Die doelwitte word of weer gedefinieer of uitgebrei ten einde die ontwikkelingsfase suksesvol te kan afhandel. Indien die doelwitte bereik word, word met die industrialisasiefase voortgegaan.

\section{Uitsette}

Die uitset van die industrialisasieproses tydens die ontwikkelingsfase is 'n gekwalifiseerde produkontwerp met 'n goedgekeurde voorlopige produksie-MRI wat as basislyn vir die industrialisasieproses dien. In Tabel 2 word 'n voorbeeld van 'n tipiese verantwoordelikheidsmatriks vir hierdie fase gegee.

\section{Die industriallsaslefase}

Tydens die industrialisasiefase is die produksieprojekbestuurder die sleutelfiguur want hy is verantwoordelik vir die optimalisering van al die produksieprosesse. Hy word deur die industrialisasiespan ondersteun. In Figuur 4 word 'n uiteensetting gegee van die industrialisasieproses tydens die industrialisasiefase.

\section{Insette}

Die inset wat die industrialisasieproses tydens die

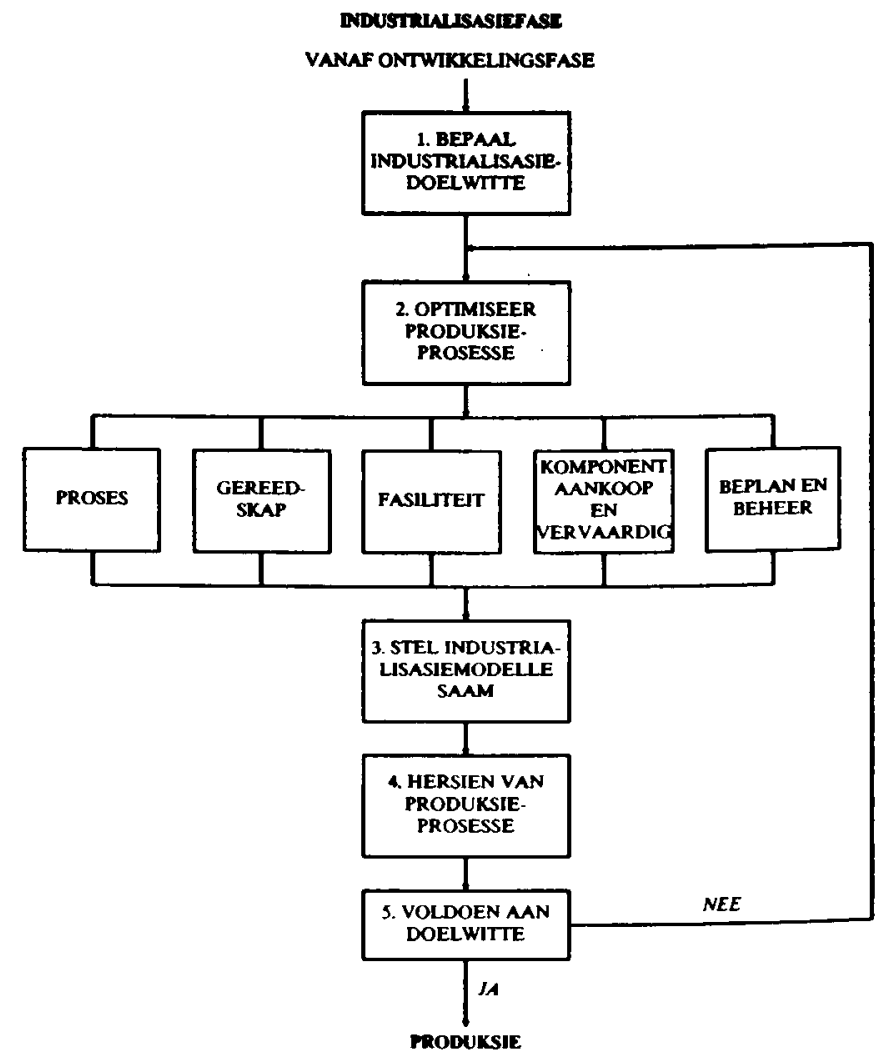

Figuur 4 Industrialisasieproses tydens die industralisasiefase 
industrialisasiefase inisieer is 'n gekwalifiseerde produkontwerp met 'n goedgekeurde voorlopige produksieMRI wat as basislyn vir die industrialisasiefase dien.

\section{Prosesaktiwiteite}

Die eerste aktiwiteit behels die bepaling en definiering van die doelwitte wat nodig is vir die industrialisasie van die gevorderde tegnologieproduk.

Die tweede aktiwiteit behels die optimalisering van al die produksieprosesse. Dit sluit die vyf aksies wat vervolgens bespreek word, in.

\section{Optimalisering van prosesse}

Voordat prosesse geoptimaliseer kan word, is dit belangrik om die kritiese proseskarakteristieke te identifiseer, te beplan en te beheer.

Produksie-optimalisering behels hoofsaaklik die optimalisering van die volgende prosestipes:

- Vestiging van basiese en sekondêre komponentvervaardigingsprosesse: dit behels hoofsaaklik die vcstiging van 'n komponentvervaardigingsvermoè by die leweransiers en verskaffers.

- Produksiebouprosesse: dit behels hoofsaaklik die selektering van die optimale bouproses, sowel as om die beste volgorde daarvoor vas te stel. Die identifisering van spesiale produksiebougereedskap en toetstoerusting.

- Beskermings- en versieringsprosesse: dit behels die tydelike of permanente bedekking van items ten einde die produk of stelsel teen die elemente te beskerm asook te versier, byvoorbeeld platering en verf.

- Inspeksie, toets en kwaliteitsbeheerproses: dit verseker dat kwaliteit in ' $n$ produk of stelsel ingebou word.

- Algemene proses: wat byvoorbeeld die gom- en plakprosesse, chemiese bestandheid van plastiek en skoonmaakprosesse insluit.

\section{Optimalisering van produksiegereedskap}

Die optimalisering van produksiegereedskap behels die beskikbaarstelling van produksiegereedskap om die doeltreffendheid van beide die man en masjien te verhoog. Dit beteken ook dat genoegsame hoeveelhede produksiegereedskap daargestel word sodat die produksie van die gevorderde tegnologiese produk nie beperk word nie, asook die daarstelling van 'n gereedskapslys wat deel van die MRI uitmaak en onder konfigurasiebestuur ressorteer.

\section{Produksiefasilitering}

Hoofsaaklik twee aktiwiteite val onder produksiefasilitering, naamlik:

Fasiliteitliggingsbeplanning Dit omvat die besluit ten opsigte van waar die fasiliteit gelex moet wees. Stoner beskryf dit soos volg:

'The objective of location planning is to position the capacity of the system so as to minimize total production and distribution costs' (1982: 226).

Fasiliteituitlegbeplanning Dit behels die besluit ten opsigte van hoe die fisiese fasiliteit gerangskik moet

Tabel 2 Tipiese verantwoordelikheidsmatriks vir die ontwikkelingsfase

Legende

V: Verantwoordelikheid

T: Taak

I: Insette

\section{INDUSTRLALUSASTIPROSES TYDENS DE ONTWITCEUNGSTASE}

\section{A INSETTE}

\begin{tabular}{|c|c|c|c|c|c|c|c|c|c|c|c|c|}
\hline i. & & & & & & & & & & & & \\
\hline & & & 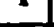 & & & & & & & & & \\
\hline ii. & Goedgekeurde ontwilkelingopesifikade & & $\mathbf{I}$ & $\mathbf{v}$ & $\mathbf{T}$ & & & & & & & \\
\hline iii.) & Stel WVS vir die ontwiltrelingsfuse op & & I & $\mathbf{v}$ & $\mathbf{T}$ & 1 & I & $\mathbf{I}$ & I & $\mathbf{I}$ & 1 & \\
\hline iv. & Bepaal koste verbonde ana elke viat van die WVS & & & $\mathbf{v}$ & $\mathbf{T}$ & I & 1 & I & & $I$ & & \\
\hline v. & Beplan ontwilkeling deur middel van netwerke & & 1 & v & $\mathbf{T}$ & I & 1 & I & & $\mathbf{I}$ & & \\
\hline vi.) & Verkty kontratk vir die uitvoering van die tase & I & VT & I & & & & & & & & \\
\hline
\end{tabular}

\section{B PROSESAKTHWTITTE}

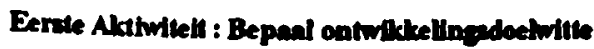

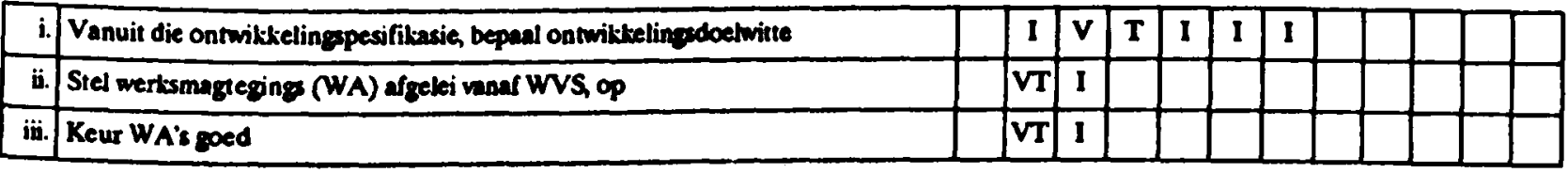


Tabel 2 (vervolg)

Legende

V: Verantwoordelikheid

T: Taak

I: Insette

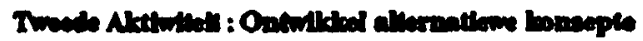

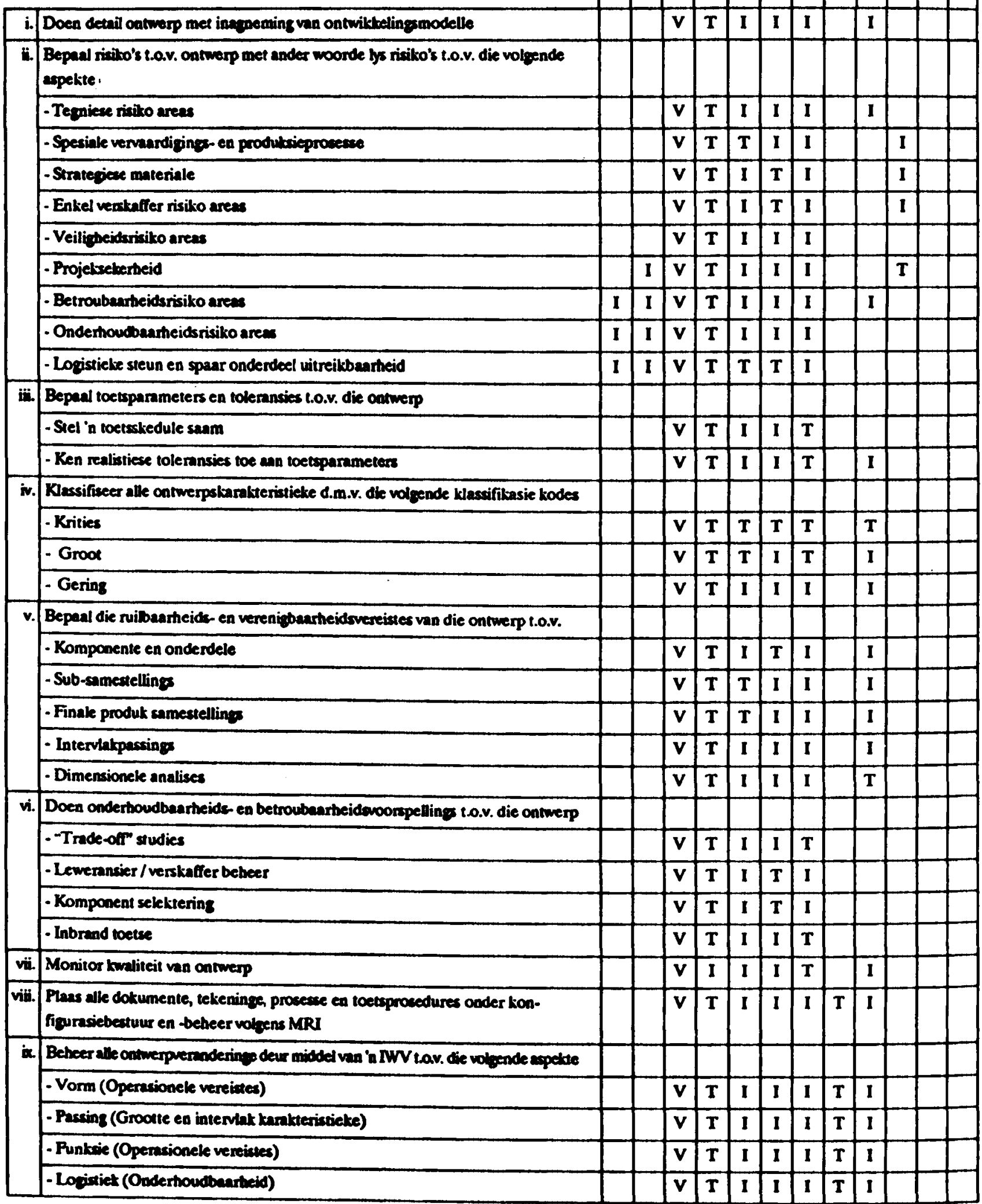


Tabel 2 (vervolg)

Legende

V: Verantwoordelikheid

T: Taak

I: Insette

Invede Altwiletl (vervoly)

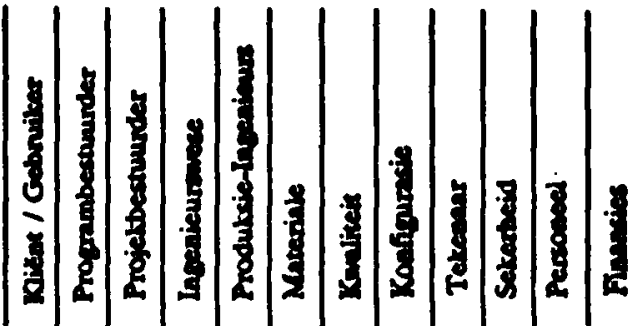

\begin{tabular}{|c|c|c|c|c|c|c|c|c|c|c|c|c|}
\hline x. & Let deurgans op na standandisasie in die ontwerp & & & $\mathbf{V}$ & $\mathbf{T}$ & $\mathbf{T}$ & $\mathbf{T}$ & $\mathbf{T}$ & & $\mathbf{T}$ & & \\
\hline \multirow[t]{6}{*}{$\mathbf{x}}$. & Bou ontwikbelingsmodelle volgens detailontwerp met ander woonde & & & & & & & & & & & \\
\hline & - Maak komponente volgens ontwerp & & & $\mathbf{V}$ & $\mathbf{T}$ & 1 & $\mathbf{T}$ & 1 & & $\mathbf{I}$ & & \\
\hline & - Vertiry onderdele volgens ontwerp & & & $\mathbf{V}$ & $\mathbf{T}$ & & $\mathbf{T}$ & 1 & & & & \\
\hline & - Stel ontwiltkelingsmodelle saam & & & $\mathbf{V}$ & $\mathbf{T}$ & $\mathbf{T}$ & & $\mathbf{I}$ & 1 & & & \\
\hline & - Opdateer ontwikkelingsdokumentasie (MRN) & & & $\mathbf{V}$ & $\mathbf{T}$ & $\mathbf{I}$ & & 1 & $\mathbf{T}$ & & & \\
\hline & - Beparal voorlopige produlstrulture (BOM) & & & $\mathbf{V}$ & $\mathbf{T}$ & $\mathbf{T}$ & & & & & & \\
\hline xii. & Toets en evalueer fisiese- en funksionele karakteristieke & & & $\mathbf{V}$ & $\mathbf{T}$ & $\mathbf{I}$ & I & $\mathbf{T}$ & & & & \\
\hline xiü. & Noteer alle afmykings en leemtes met betrelting tot die ontwerp & & & $\mathbf{V}$ & $\mathbf{T}$ & $\mathbf{I}$ & I & $\mathbf{T}$ & & & & \\
\hline xiv. & Stel voorlopige produksie dokumentasie saam & & & $\mathbf{V}$ & $\mathbf{T}$ & $\mathbf{T}$ & I & 1 & $\mathbf{I}$ & & 1 & \\
\hline \multirow[t]{3}{*}{$\mathbf{x v}$} & Real 'n tegniese hersiening van dic ontwerp verydering & I & 1 & $\mathbf{V T}$ & & & & & & & & \\
\hline & - Tegniese werkverrigtingspesifikasies & & & & & & & & & & & \\
\hline & - Ontwilikelingsdoelwitte & & & & & & & & & & & \\
\hline
\end{tabular}

Derde Aldwriteif : Voldoen ann doelwitte

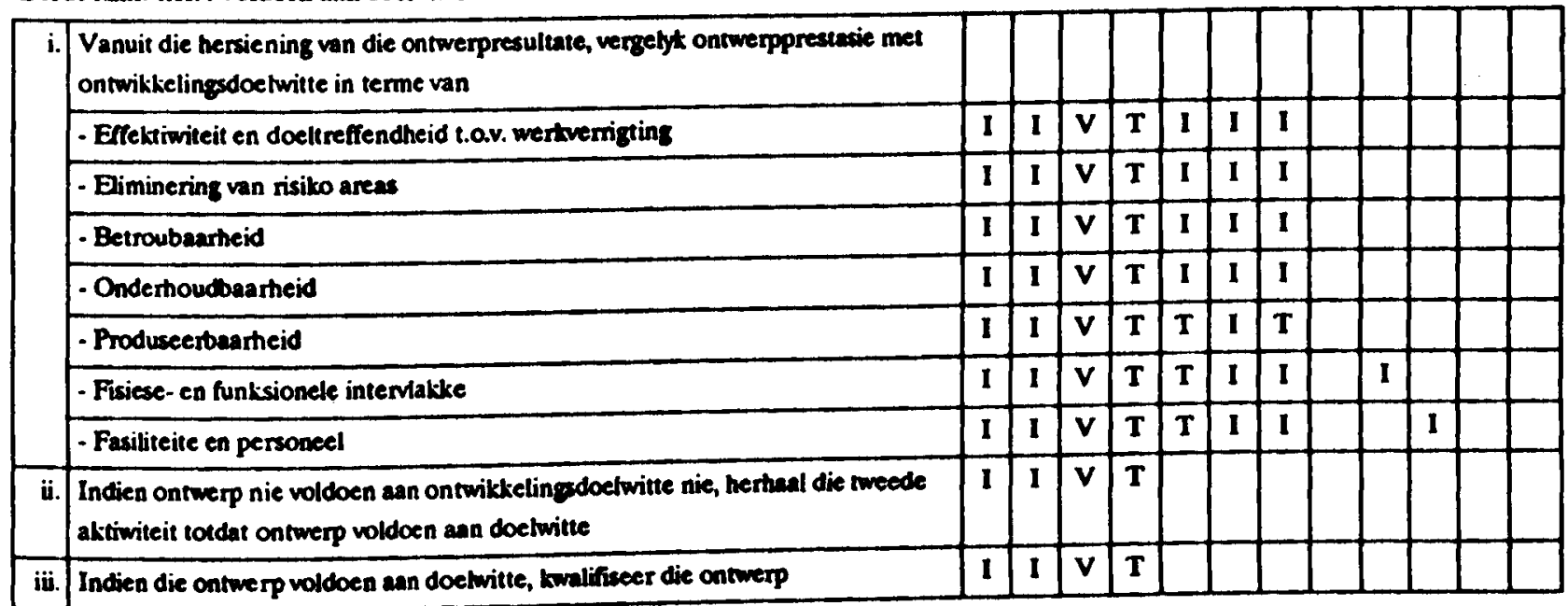

Vierde Alutwitets : Kwallibeer die ontwerp

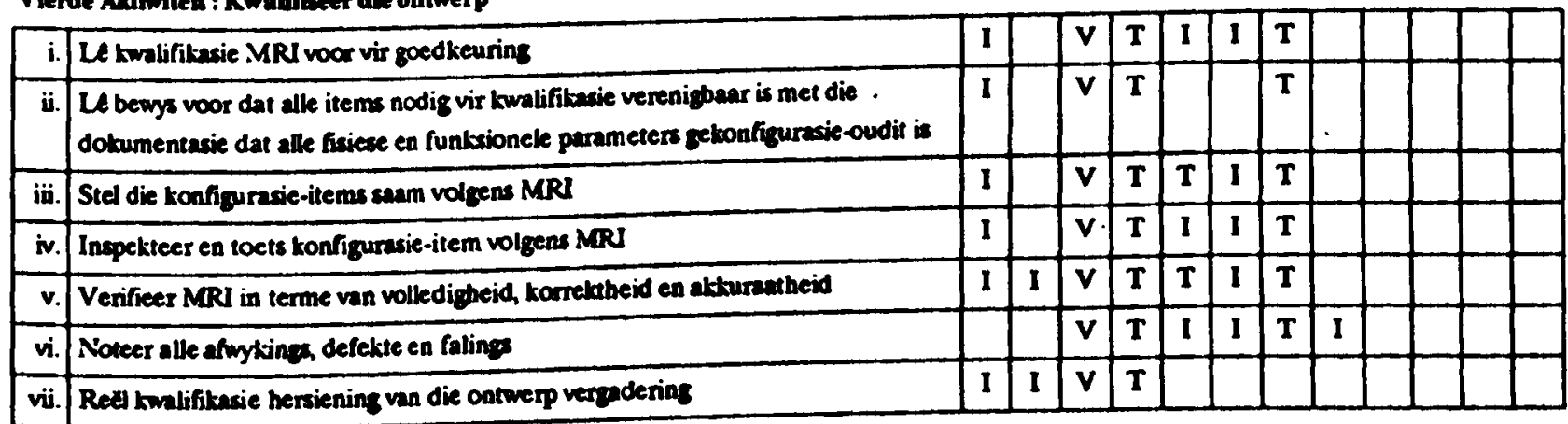


Tabel 2 (vervolg)

Legende

V: Verantwoordelikheid

T: Taak

I: Insette

Vlente Alatuliele (wervola)

\begin{tabular}{|c|c|c|c|c|c|c|c|c|c|c|c|c|}
\hline \multirow[t]{2}{*}{ viii. } & $\begin{array}{l}\text { Vergelyk en evalueer die preatmie van die ontwexp teenoor die doelwitte in } \\
\text { terme van }\end{array}$ & & & & & & & & & & & \\
\hline & - Werkverrigtingopesifikacie & 1 & $\mathbf{I}$ & $\mathbf{V}$ & $\mathbf{T}$ & I & $\mathbf{I}$ & $\mathbf{I}$ & & & & \\
\hline & - Betroubaarbeid & 1 & I & $\mathbf{V}$ & $\mathbf{T}$ & $\mathbf{I}$ & I & I & & & & \\
\hline & - Onderhoudbearheid & I & I & $\mathbf{V}$ & $\mathbf{T}$ & $\mathbf{I}$ & I & I & & & & \\
\hline & - Voorsien produlssie risiko's & I & I & $\mathbf{v}$ & $\overline{\mathbf{T}}$ & $\overline{\mathbf{T}}$ & $\overline{\mathbf{T}}$ & $\mathbf{T}$ & & & & \\
\hline & - Produl of stelselspesifilataic & I & & $\mathbf{V}$ & $\mathbf{T}$ & I & 1 & $\mathbf{I}$ & $I$ & & & \\
\hline & - Fisiese- en funlssionele intervialdse & I & & $\mathbf{V}$ & $\mathbf{T}$ & 1 & $\mathbf{I}$ & $\mathbf{I}$ & & I & & \\
\hline & - Fasiliteirc en personeel & I & & $\bar{v}$ & $\overrightarrow{\mathbf{T}}$ & $\overline{\mathbf{T}}$ & 1 & I & & & I & \\
\hline ix. & Siel kwalifibasieveraleg senem & I & I & $\overline{\mathrm{VT}}$ & $I$ & I & 1 & $I$ & & & & \\
\hline
\end{tabular}

Vyide Alatwitell : Voldoen ean doelwitus

\begin{tabular}{|c|c|c|c|c|c|c|c|c|c|c|c|c|}
\hline i. & Evalueer kwalifikasieresultate en vergeblyt met ontwitkelingsdoelwitte & $\mathbf{I}$ & I & $\mathbf{v}$ & $\mathbf{T}$ & 1 & I & I & & & & \\
\hline ii. & Indien doetwitte nie bereik word nie, begin weer met dic eerste aktiwiteit & I & I & $\mathbf{V}$ & $\mathbf{T}$ & 1 & I & I & I & I & I & \\
\hline iii. & $\begin{array}{l}\text { Indien die doetwilte bereik is, is die ontwerp gelwatifisear en kan voongegann } \\
\text { word met die industrialisasiefase }\end{array}$ & I & I & $\mathbf{V}$ & $\mathbf{T}$ & 1 & 1 & 1 & & & & \\
\hline
\end{tabular}

\section{c. CITSETTE}

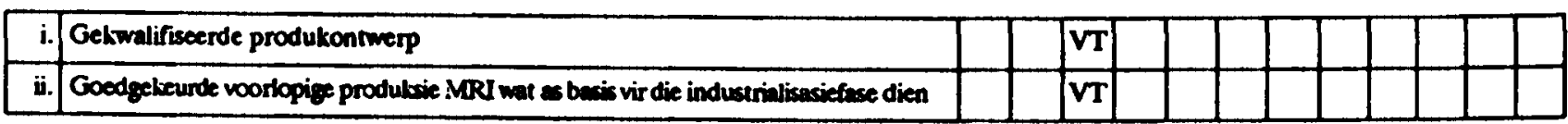

word. Volgens Stoner is dit belangrik omdat:

'A good layout minimizes material handling, maximizes worker and equipment efficiency, and satisfies a host of other factors' (1982: 226).

Die industrialisasie van gevorderde tegnologieprodukte met lae volume vereis 'n lotproduksie-fasiliteituitleg. Gevolglik word die nuwe produk in die bestaande produksiefasiliteit met sy tiperende lotdepartemente opgeneem.

Industrialisasie van komponentaankope en -vervaardiging

Maak-of-koop is een van die probleme wat die meeste verwarring vir die produksieprojekbestuurder meebring. Van die belangrikste faktore wat tydens die maak-ofkoopbesluit in ag geneem word, is skedule, koste, fasiliteite en mannekrag. Dit vereis 'n deurlopende bewustheid van die impak op koste, skedule en kwaliteit.
Volgens Maynard (1970: 123) bestaan 'n logiese en sistematiese benadering tot makk-of-koopbesluitneming uit vyf hoofstappe. Die eerste stap is die effektiewe benutting van die huidige hulpbronne van die organisasie. Die tweede stap is 'n logiese en sistematiese proses waartydens feite versamel, geanaliseer en geevalueer word. Die derde stap behels die besluitnemingsproses waartydens al die tersaaklike faktore in oénskou geneem en oorweeg word ten einde 'n goeie besigheidsbesluit te kan neem. Die vierde stap behels die nodige bestuursaanleg ten einde te verseker dat die besluit geïmplementeer en deurgevoer word. Die vyfde stap behels die motivering, verslaggewing en bekendmaking van die finale resultate ten einde die mate van sukses van die besluitnemingsaksies te evalueer.

Gevolglik moet alle komponente wat aangekoop word se spesifikasies tot in die fynste besonderhede in die nodige dokumentasie of tekeninge vervat wees. Komponente wat gemaak word, ondergaan 'n industrialisasieproses waartydens elke stap van die vervaardigings- 
proses asook die tipe toerusting, gereedskap, setmate en ykmate benodig tydens elke spesifieke stap van die vervaardigingsproses, gedokumenteer word.

Maynard (1970: 7-24) wys daarop dat maak-of-koopbesluite 'n spanpoging moet wees, met ander woorde groter betrokkenheid en deelname van die organsisasie rondom die uitkoms van die besluit behoort plaas te vind.

\section{Produksiebeplanning en -beheer}

Produksiebeplanning en -beheer is die proses waartydens die organisasie besluit op die hulpbronne wat vir toekomstige produksie-aktiwiteit benodig word. Dit behels ook die toedeling van hulpbronne ten einde die verlangde uitsetproduk, in genoegsame hoeveelhede, teen die laagste moontlike prys, te kan produseer. Produksiebeplanning bepaal dus die raamwerk waarbinne die gedetaileerde skedules en voorraadbeheerplanne moet opereer (Maynard, 1970: 3-85). Produksiebeheer beteken in dié verband die aanpassing van die produksieaktiwiteite sodat dit aan die beplanningsvereistes kan voldoen.

Alhoewel produksiebeplanning en -beheer in groot detail ontwerp kan word, bly dit steeds 'n bestuursuitdaging. Die rede hiervoor is dat enige produksiebeplanning- en -beheerstelsel gebaseer is op vooruitskattings van die toekomstige behoeftes en gevolglik beïnvloed die korttermynbesluite die werking van die stelsel (Stoner, 1982: 228).

Vir die doel van die industrialisasieproses is dit nodig on produksiestandaarde, wat as inset vir die groter pro- duksiebeplanning en -beheerstelsel dien, daar te stel. Produksiestandaarde bestaan hoofsaaklik uit twee aktiwiteite:

Bepaling van materiaalstandaard Dit begin met die daarstelling van 'n gedetailleerde produksiestruktuur. Die produkstruktuur gee 'n uiteensetting van elke item wat tydens die produsering van 'n produk benodig word. Materiaalkoste word dus direk aan elke item in die produksiestruktuur toegedeel. Opsommend gesien gee dit dus die totale direkte materiaaalkoste vir die produsering van die produk.

Bepaling van die arbeidstandaard Dit begin met die daarstelling van 'n vervaardigingsroete ('routing') wat 'n uiteensetting gee van die hoeveelheid tyd wat vir arbeid benodig word in die uitvoering van elke produksieaktiwiteit. Die totale direkte materiaalkoste plus die totale direkte arbeidskoste bepaal dus die produksiestandaard vir die produk.

Die derde aktiwiteit wat plaasvind is die samestelling van die industrialisasiemodelle. Tydens dié aktiwiteit word die geoptimaliseerde produksieprosesse soos uitcengesit in die tweede aktiwiteit asook die voorlopige produksie-MRI op die proef gestel.

Die vierde aktiwiteit behels die industrialisasiehersiening. Tydens die hersiening word die industrialisasietoetsresultate geèvalueer en die nodige korrektiewe aksies voorgestel.

Die vyfde aktiwiteit is die bereiking van die industrialisasieprosesdoelwitte naamlik: die produsering van kwaliteitprodukte teen 'n aanvaarbare prys. Indien nie an die doelwitte voldoen word nie, word teruggekeer

Tabel 3 Tipiese verantwoordelikheidsmatriks vir die industrialisasiefase

Legende

V: Verantwoordelikheid

T: Taak

I: Insette

\section{INDISTRIALUSASIEPROSES TYDENS DIE NDDUSTRUALUSASIETASE}

A. INSETTE

\begin{tabular}{|c|c|c|c|c|c|c|c|c|c|c|c|c|c|}
\hline i. & Projekbasistyn vanuit ontwikkelingofase & $\mathbf{I}$ & 1 & $\mathbf{v}$ & $\mathbf{T}$ & & & & & & & & \\
\hline ii. & Gelwalifiseerde produkontwerp & & 1 & $\mathbf{V}$ & I & $\mathbf{T}$ & & & & & & & \\
\hline iii. & Goedgekeurde voorlopige produlosic MRI & & & & $\mathbf{v}$ & $\mathbf{T}$ & $\mathbf{T}$ & & $\mathbf{I}$ & I & & & \\
\hline iv. & Sted WVS vir industrialisasiefase op & & 1 & $\mathbf{v}$ & I & $\mathbf{T}$ & 1 & $\mathbf{I}$ & I & $\mathbf{I}$ & $\mathbf{I}$ & I & \\
\hline v. & Beplan industrialisasie deur middel van netwertic (PERT) & & $\mathbf{I}$ & $\mathbf{v}$ & $\mathbf{I}$ & $\mathbf{T}$ & $\mathbf{I}$ & 1 & $\mathbf{I}$ & I & & & \\
\hline vi. & Vertiry kontrak vir die uitwoering van die fase & I & VT & $\mathbf{I}$ & & & & & & & & & \\
\hline
\end{tabular}

\section{PROSESAKTIMTTEITE}

Eerste Akthwitetl : Bepaal Industrialtsestedoetmitte

\begin{tabular}{|r|l|r|r|r|r|r|r|r|r|r|r|r|r|}
\hline i. & Vanuit projeltbasistyn bepaal die doelwitte vir die industrialisasiefase & I & V & I & T & I & I & I & I & I & & \\
\hline ii. & Stel werlsmagtiging afgelei vanaf WVS op & & I & VT & I & I & I & I & I & I & & & \\
\hline iii. & Stel voorlopige produlvatrukture in vermardiginganoetc op & & & V & I & T & I & I & & I & & & \\
\hline
\end{tabular}


Tabel 3 (vervolg)

Legende

V: Verantwoordelikheid

T: Taak

I: Insette

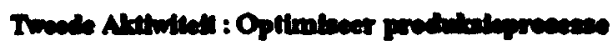

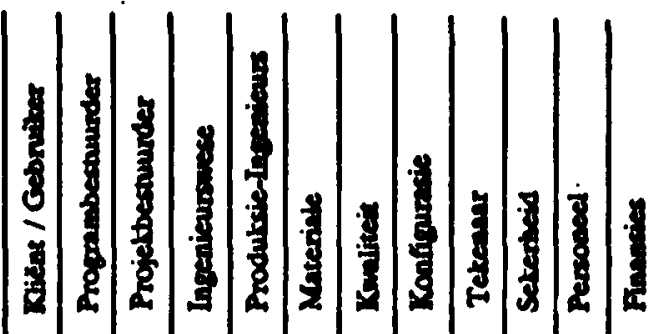

\begin{tabular}{|c|c|c|c|c|c|c|c|c|c|c|c|c|c|}
\hline \multirow[t]{6}{*}{ i. } & Optimineer prosesese & & & & & & & & & & & & \\
\hline & - Veatig beniese en sekondlere bomposent van verveardigingoprosesse & & & $\mathbf{V}$ & I & $\mathbf{T}$ & I & I & & I & $\mathbf{I}$ & & \\
\hline & - Produbsie bouprosesse & & & $\mathbf{V}$ & I & $\mathbf{T}$ & $\mathbf{I}$ & I & & $\mathbf{I}$ & & & \\
\hline & - Besterming en versieringoprocesse & & & $\mathbf{V}$ & $\mathbf{I}$ & $\mathbf{T}$ & $\mathbf{I}$ & I & I & & & & \\
\hline & - Inspetsie, toets en kwaliteitbehoer prosease & & & $\mathbf{V}$ & I & $\mathbf{T}$ & $\mathbf{I}$ & $\mathbf{T}$ & & 1 & & & \\
\hline & - Algemene processe & & & $\mathbf{v}$ & I & $\mathbf{T}$ & 1 & I & I & & & & \\
\hline \multirow[t]{10}{*}{ ï.) } & Optimiseer produlasiegereedstap & & & & & & & & & & & & \\
\hline & - Gietuuk gereedskap vir giet en worm prosease & & & $\mathbf{v}$ & I & $\mathbf{T}$ & $\mathbf{T}$ & I & & & $\mathbf{I}$ & & \\
\hline & - Komponentvervaardigingagereedstinp & & & $\mathbf{V}$ & & $\mathbf{T}$ & $\mathbf{T}$ & $\mathbf{I}$ & & & $\mathbf{I}$ & & \\
\hline & - Spesiale bougereedslinp & & & $\mathbf{V}$ & I & $\mathbf{T}$ & & I & & & & & \\
\hline & - Speciale setmate & & & $\mathbf{V}$ & I & $\mathbf{T}$ & 1 & & $\mathbf{I}$ & & & & \\
\hline & - Meet instrumente en ytimates & & & $\mathbf{V}$ & I & $\mathbf{T}$ & $\mathbf{I}$ & $\mathbf{T}$ & & & & & \\
\hline & - Spesiale toetsgereedskap en toetwetmate & & & $\mathbf{v}$ & I & $\mathbf{T}$ & & $\mathbf{T}$ & & & & & \\
\hline & - Bepaal produbsrievolumes & $\mathbf{I}$ & I & $\mathbf{V T}$ & & $\mathbf{I}$ & 1 & I & & $\mathbf{I}$ & & & \\
\hline & - Bepaal produlssie leweringstempo's & I & I & $\mathbf{V T}$ & & $\mathbf{I}$ & 1 & $\mathbf{I}$ & & $\mathbf{I}$ & & & \\
\hline & - Bepaal lot- en draergroottes & & & $\mathbf{V}$ & & $\mathbf{T}$ & 1 & & & I & & & \\
\hline \multirow[t]{11}{*}{ ii.. } & Optimiseer produlssiefasiliteit uitles & & & & & & & & & & & & \\
\hline & - Fasiliteitliegings beplanning behels & & & & & & & & & & & & \\
\hline & a. Bepaal die lizroingovereistes & & & $\mathbf{V}$ & I & $\mathbf{T}$ & & $\mathbf{I}$ & & $\mathbf{I}$ & I & & \\
\hline & b. Bepaal al die moontlike ligeingopesiea & & & $\mathbf{V}$ & I & $\mathbf{T}$ & & I & & I & $\mathbf{I}$ & & \\
\hline & c. Evalueer ellse opsic & & & $\mathbf{v}$ & $\mathbf{I}$ & $\mathbf{T}$ & & I & & $\mathbf{I}$ & I & & \\
\hline & d. Selekteer dic beste ligring & & & $\mathbf{v}$ & & $\mathbf{T}$ & & & & & & & \\
\hline & - Fasibteituitlegteplanning behels & & & & & & & & & & & & \\
\hline & a. Last ruimte toe vir produksie-, nie-produktiewe en steunfasiliteite & & & $\mathbf{v}$ & I & $\mathbf{T}$ & & I & & I & 1 & & \\
\hline & b. Bepanal tipe produlssieprosea, bv. projet of bontenie of bo & & & $\mathbf{V}$ & & $\mathbf{T}$ & $\mathbf{I}$ & I & & I & $\mathbf{I}$ & & \\
\hline & c. Minimeer materiaal hantering & & & $\mathbf{v}$ & & $\mathbf{T}$ & 1 & & & & & & \\
\hline & d. Maksimeer man en masjien effektiviteit & & & $\mathbf{v}$ & & $\mathbf{T}$ & 1 & I & & $\mathbf{I}$ & & & \\
\hline \multirow[t]{9}{*}{ iv. } & Industrialiseer komponent aankope en komponentvervandiging & & & & & & & & & & & & \\
\hline & - Maak-of-koop besluitneming behels & & & & & & & & & & & & \\
\hline & 1. Effektiewe benulting van huidige organisasievermot en hulporonne & & & $\mathbf{V}$ & $\mathbf{I}$ & $\mathbf{T}$ & $\mathbf{T}$ & I & & $\mathbf{I}$ & 1 & & \\
\hline & $\begin{array}{l}\text { b. Versamel, analiseer en evalueer feite to.v. organisasievermot bapasiteit en } \\
\text { hulpbronne }\end{array}$ & & & $\mathbf{v}$ & & $\mathbf{T}$ & $\mathbf{T}$ & & & & & & \\
\hline & c. Maat-of toop besluitnemingoproces & & & $\mathbf{v}$ & & $\mathbf{T}$ & $\mathbf{T}$ & I & & $\mathbf{I}$ & $\mathbf{1}$ & & \\
\hline & d. Beaturoverbintenis by die implimenteringaproces & & $\mathbf{I}$ & $\mathbf{V T}$ & & & & & & & & & \\
\hline & e. Verdagewing en bekendstelling van finale resulhate & & & $\mathbf{V} \mathbf{r}$ & & & & & & & & & \\
\hline & - Dateer produbstruktuur en MRJ op & & & $\mathbf{v}$ & & $\mathbf{T}$ & & & $\mathbf{T}$ & & & & \\
\hline & - Monicor intomende inspetsieproses & & & $\mathbf{V}$ & & $\mathbf{T}$ & 1 & $\mathbf{T}$ & & & & & \\
\hline
\end{tabular}


Tabel 3 (vervolg)

Legende

V: Verantwoordelikheid

T: Taak

I: Insette

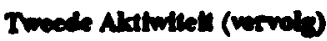

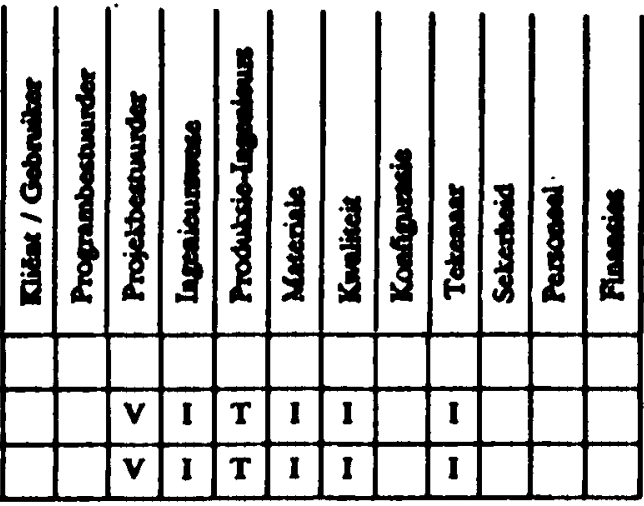

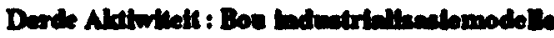

\begin{tabular}{|c|c|c|c|c|c|c|c|c|c|}
\hline i.] & Siel industrializaciemodelle sanm volgens voorlopip produbsie MRI & $\mathbf{v}$ & I & $\mathbf{T}$ & I & $\mathbf{I}$ & $\mathbf{I}$ & $\mathbf{I}$ & \\
\hline ï. & Beproel die prosesse sooc geoptimiseer in eerete altiwiteir & $\mathbf{v}$ & $\mathbf{I}$ & $\mathbf{T}$ & 1 & I & $\mathbf{I}$ & $\mathbf{I}$ & \\
\hline iit. & Inspelteer induatrialisaciemodelle volfens anuaardingmorme en spesiflionie & $\mathbf{v}$ & $\mathbf{I}$ & $\mathbf{T}$ & I & I & & I & \\
\hline in. & Noteer alle afwyting en loemtes to.v. die produbsieprocesse & $\mathbf{v}$ & $\mathbf{I}$ & $\mathbf{T}$ & $\mathbf{I}$ & I & $\mathbf{I}$ & 1 & \\
\hline $\mathbf{v}$ & Evaluear die produlsieproseovermot & $\mathbf{V}$ & $\mathbf{I}$ & $\mathbf{T}$ & $\mathbf{I}$ & $\mathbf{I}$ & I & I & \\
\hline vi. & Opdateer die produbsie MRI & $\mathbf{v}$ & $\boldsymbol{I}$ & $\mathbf{T}$ & $\mathbf{I}$ & $\mathbf{I}$ & $\mathbf{T}$ & $\mathbf{I}$ & \\
\hline
\end{tabular}

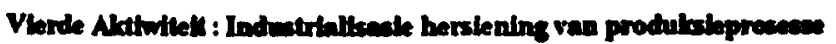

\begin{tabular}{|c|c|c|c|c|c|c|c|c|c|c|c|}
\hline i. & Reel 'n hersiening van die produlssieprosesse & 】 & I & $\mathbf{v T}$ & & I & & & & & \\
\hline ï. & Evalueer prosesvermot & I & I & $\mathbf{v}$ & I & $\mathbf{T}$ & I & I & I & I & \\
\hline iii. & Toereikendheid, doeltreffendheid en komektheid van gereedstap & I & I & $\mathbf{v}$ & I & $\mathbf{T}$ & $\mathbf{I}$ & I & $\mathbf{I}$ & $\mathbf{I}$ & \\
\hline iv. & Evalueer fasiliteituitles & $\mathbf{I}$ & I & $\mathbf{v}$ & I & $\mathbf{T}$ & $\mathbf{I}$ & I & I & I & \\
\hline v. & Evalueer die kmaliteit van die produk t.o.v. die produbsieproseovermot & $\mathbf{I}$ & I & $\mathbf{v}$ & I & $\mathbf{T}$ & I & $\mathbf{T}$ & I & I & \\
\hline vi. & Evalueer produlssie MRI & $\mathbf{I}$ & I & $\mathbf{v}$ & I & $\mathbf{T}$ & I & I & $\mathbf{T}$ & I & \\
\hline
\end{tabular}

Vyede Altwkelt : Voldoen san doelwhes

\begin{tabular}{|c|c|c|c|c|c|c|c|c|c|c|c|c|}
\hline i. & $\begin{array}{l}\text { Vanuit hersiening van die produksieproses se resultate vergelyt produksieproces } \\
\text { prestasie met industrialisasie dochitte in terme van }\end{array}$ & & & & & & & & & & & \\
\hline & - Doeltreffendheid & 1 & $I$ & VT & 1 & $I$ & I & 1 & I & I & & \\
\hline & - Effcktiwiteit & 1 & 1 & $\mathbf{V T}$ & I & I & I & $\mathbf{I}$ & 1 & I & & \\
\hline & - Produltiviteit & 1 & 1 & $\mathbf{T}$ & I & I & $\mathbf{I}$ & 1 & 1 & I & & \\
\hline & - Kapasiteitsvermol & 1 & 1 & $\mathbf{V T}$ & 1 & I & I & $\mathbf{I}$ & 1 & I & & \\
\hline & - Produlsstandaard & 1 & I & $\mathbf{V T}$ & 1 & I & I & $\mathbf{I}$ & 1 & I & & \\
\hline & - Produt kmaliteit & 1 & I & VT & 1 & $\mathbf{I}$ & $I$ & I & I & I & & \\
\hline & - Produlisic MRI & 1 & I & VT & I & I & I & 1 & I & I & & \\
\hline ì. & 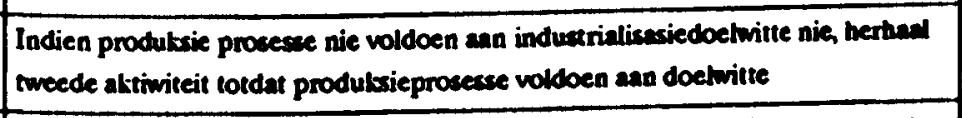 & 1 & I & $\mathbf{v}$ & $I$ & $\mathbf{T}$ & 1 & 1 & 1 & $\mathbf{I}$ & & \\
\hline iii. & $\begin{array}{l}\text { Indien die produlsxieprocesse voldoen asa induatrialisasiedoelwitte. gan voort } \\
\text { met volstantae produlssic }\end{array}$ & I & I & $\mathbf{v}$ & $\mathbf{I}$ & $\mathbf{T}$ & I & 1 & 1 & I & & \\
\hline
\end{tabular}

\section{c. IITSETTE}

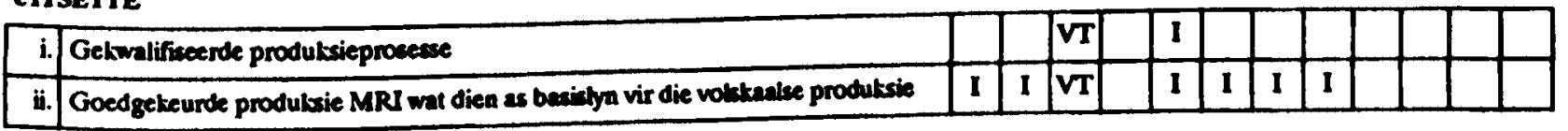


na die eerste aktiwiteit om die produksieprosesse verder te optimaliseer. Indien dan aan die doelwitte voldoen word, word orgegaan na die volskaalse produksie van die produk.

\section{Uitsette}

Die uitset van die industrialisasieproses tydens die industrialisasiefase is gekwalifiseerde produksieprosesse met 'n goedgekeurde produksie-MRI wat as basislyn vir die produksiefase dien.

\section{Samevatting}

Uit die artikel blyk dit dat die industrialisasie van gevorderde tegnologieprodukte met lae volume 'n komplekse taak is. Dit blyk egter dat die projekbestuursbenadering 'n moontlike meganisme is waardeur gevorderde tegnologieprodukte bestuur kan word. Binne die raamwerk van projekbestuur dien die prosesbenadering op sy beurt weer as 'n moontlike meganisme vir die industrialisasie van gevorderde tegnologieprodukte met lae volume. Met behulp van die projekbestuursbenadering en die prosesbenadering is gepoog om ' $n$ industrialisasiemodel daar te stel. Die industrialisasiemodel tesame met die verantwoordelikheidsmatriks kan as raamwerk dien vir die industrialisasieproses van gevorderde tegnologieprodukte met lae volume.

\section{Woordomskrywing}

Met inagneming van die lengte van die artikel, word nie volledige teoretiese of empiriese bewyse gelewer vir die keuse van bepaalde tegnieke of uitgangspunte nie. Ter ondersteuning van uitgangspunte word enkele begrippe kortliks omskryf.

\section{Projekbestuur}

Projekbestuur is wanneer ' $n$ bestuurder alleen verantwoordelikheid dra vir die proses van beplanning, organisering, leiding en beheer van dic gekombineerde pogings van personeel en funksionele departemente om die projekdoelwitte volgens spesifikasies, begroting en skedule te bereik.

\section{Matriksorganisasie}

Struckenbruck (1982: 64) definieer 'n matriksorganisasie as 'n organisasie waarin daar twee of veelvoudige bestuursverantwoordelikhede en aanspreeklikhede is. In 'n matriksorganisasie geskied bevelvoering dus langs 'n funksionele sowel as 'n projeklyn.

In hierdie organisasiestruktuur is die projekbestuurder verantwoordelik vir die projek in sy geheel, terwyl die werkverrigting van die onderskeie fases van die projek se lewensiklus die verantwoordelikhede van die betrokke funksionele bestuurders bly. In 'n matriksorganisasie bepaal die projekbestuurder wat gedoen moet word, terwyl die funksionele bestuurder bepaal

Figuur 5 Vloeidiagram van 'n hipotetiese proses

\section{PROSES}

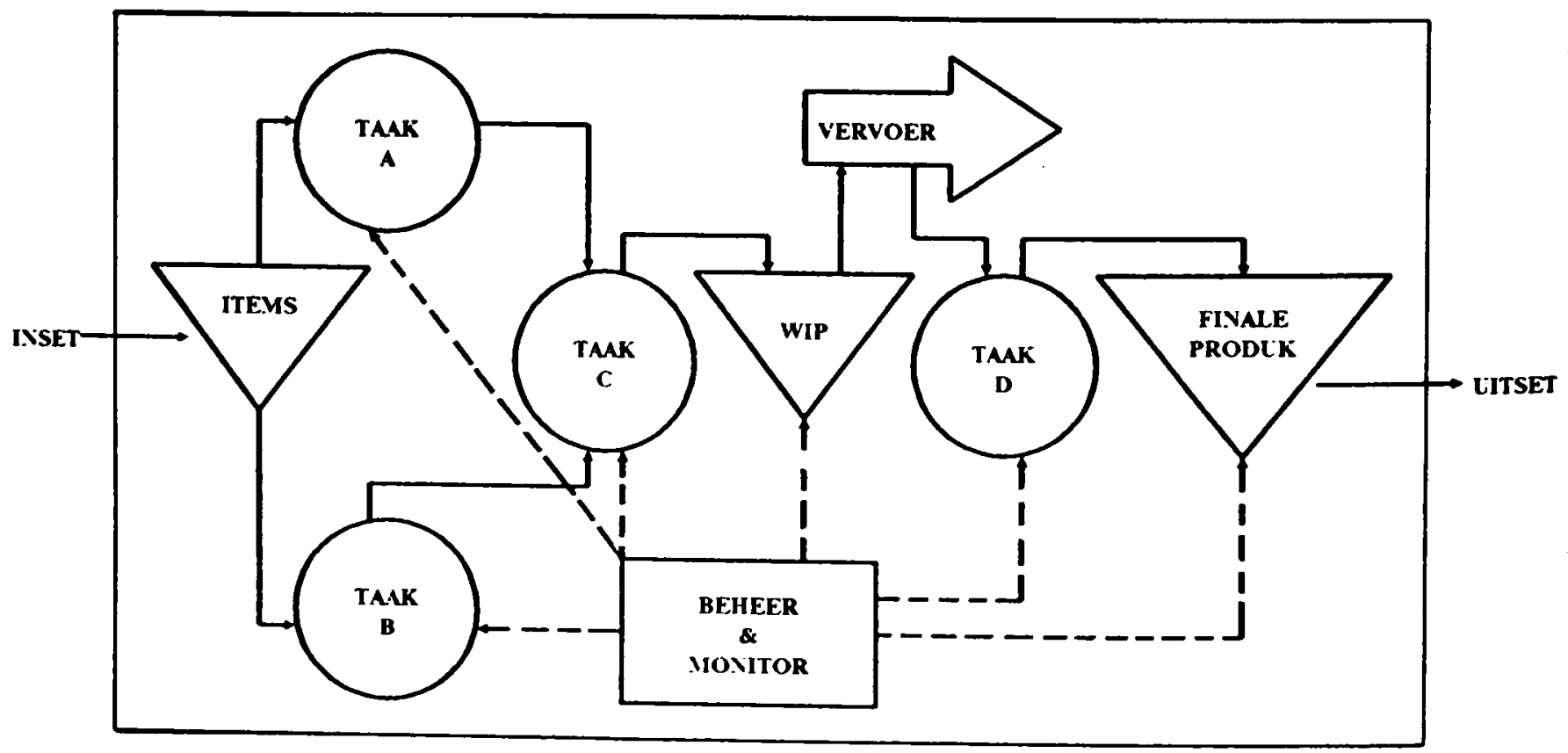


hoe dit gedoen moet word. Die sukses van die projek word in 'n groot mate bepaal deur die vermoèns en vaardighede van die projekbestuurder sowel as die bereidwilligheid van die funksionele bestuurder om sy samewerking te gee.

\section{Proses en prosesbenadering}

Stoner (1982: 218) definieer 'n proses soos volg: '(a) set of components whose function is to transform a set of inputs into some desired output'.

'n Proses is dus 'n versameling van aktiwiteite wat aanmekaar verbind is deur die vloei van inligting sowel as items wat 'n gegewe stel insette transformeer in 'n spesifieke uitset.

Die waarde van die uitset is gewoonlik hoèr as dié van die inset. Tydens 'n proses kan inligting sowel as items tydens die transformasie gestoor word. 'n Proses kan deur middel van 'n vloeidiagram beskryf word soos in Figuur 5 waar die vloeidiagram van 'n hipotetiese proses beskryf word.

Die vernaamste komponente van 'n proses is die omgewing, insette, prosesaktiwiteite en uitsette.

\section{Summary}

A noticeable revolution, in the manner in which products are produced, has occurred since World War

II. This change was mainly stimulated by three factors:

- Firstly, there is a growing awareness of prosperity and progress which depend on an increase in productivity.

- Secondly, a large amount of capital has been spent on research and development, which caused a rapid change in technology.

- Thirdly, the complexity of both the product and the technique to produce it, are increasing. Therefore there exists a growing need for more skill and involvement on all levels of the organisation.

In order to meet the above-mentioned requirements, the manufacturing organisations of today will have to place more emphasis on the thorough industrialisation of high-technology products.

The study of several high-technology organisations has shown that typical problems are experienced with the transfer of high-technology products from development to production. These problems include communication, involvement during the different project life-cycle phases, cultural differences between development and production, documentation management, component manufacturing, instruments, manpower shortages and low volumes. The various organisations make use of a single industrialisation department during the transfer of the high-technology products from development to production.

The study of the project management approach has shown that it is an effective mechanism to deal with the problems already mentioned and for the management of technology products with a low volume. It is important that the new high-technology product will have a single integrated focus point of responsibility. This will ensure that both top management and the client have access to project information through one function. It is further important that the new technology product is planned and managed on an integrated basis. Here the supplementary use of work-division structures and network analysis can lead to the establishment of optimum planning and control.

\section{Conclusion}

It is evident that the industrialisation of high-technology products with low volume is a complex task. Currently, industrialisation is seen as a task that begins and ends during the industrialisation phase. Owning to the rapid change in high technology new demands are made regarding the development of high-technology products. The incorporation of state-of-the-ant technology or a new combination of technology is furthermore required. This leads to the fact that it is impossible for a single person or department to specialise over such a wide spectrum of technology. Thus greater involvement of the organisation during the industrialisation process is required. It is furthermore important that the industrialisation process starts with the investigation phase in order that all possible production-orientated activities can be considered.

\section{Recommendation}

The greater organisational involvement, which commence with the investigation phase, include the contracting of specialists in all disciplines of the organisation. Therefore specialists in every technical and scientific field of the organisation as a whole. Of them is expected to make a contribution to all possible production-orientated activities. This greater organisational involvement or participation is referred to as the industrialisation team.

In order to ensure effective co-operation the industrialisation team has to be part of the project team. The project manager (single integrated focus point of responsibility) of the project team can vary during the different phases of the project life cycle.

It is furthermore evident that the matrix structure is an appropriate structure for the achievement of goals, as it brings forth the specialised skills of the organisation as a whole in order to manage the industrialisation process in an effective manner. Work-division structures in combination with the responsibility matrix can be used to appoint responsibilities to the various members of the industrialisation team, with regard to all productionorientated activities. A model of the industrialisation of high-technology products with low volume based on the process approach is recommended. This industrialisation model combined with the responsibility matrix can serve as a framework for the industrialisation process.

\section{Venwysings}

American Graduate University. 1981. Project manager's handbook, Vol. 1. Califomia: Procurement Associates.

Archibald, R.D. 1976. Managing high-technology programs and projects. New York: Wiley.

Armscor. 1984. Project management and technical assurance requirements: internal production. 2nd ed. Pretoria. 
Barrett, T.H. 1986. Research and manufacturing, share a common world. Research Management, XXIX (2): 23-25, Maart-April.

Burt, D.N. \& Soukup, E.R. 1985. Purchasing's role in new product development. Harv. Bus. Rev., 85(5): 90-97, September-October.

Clawson, R.T. 1985. Controlling the manufacturing start-up. Harv. Bus. Rev., 85(3): 6-20, May-June.

Frosch, R.A. 1984. R \& D choices and technology transfer. Research Management, xxvii(3): 11-14, May-June.

Gray, H.J. 1985. Research and manufacturing should be partners. Research Management, xxxciii(6): 6-8, November-December.

Maynard, H.B. Ed. 1970. Handbook of modern manufacturing management. New York: McGraw Hill.

Raad vir Geesteswetenskaplike Navorsing. 1981. Onderwysvoorsiening in die RSA. Pretoria.

Shannon, R.E. 1980. Engineering management. New York: Wiley.

Stoner, J.A.F. 1982. Management. 2nd ed. Englewood Cliffs, New Jersey: Prentice-Hall.

Struckenbruck, L.C. 1982. The implementation of project management: the professional's handbook. 4th ed. Philiphanes: Wesley.

Wolff, M.F. 1985. Bridging the R \& D interface with manufacturing. Research manufacturing, xxciii(i): 9-11, January-February. 